ELECTRONUCLEAR FISSILE FUEL RRODUCTION

\title{
Linear Accelerator Fuel Regenerator and Producer LAFR and LAFP
}

Meyer Steinberg, J. R. Powell, H. Takahashi, P. Grand, and H. J. C. Kouts Department of Nuclear Energy Brookhaven National Laboratory.

Upton, New York 11973

Apri1 1978

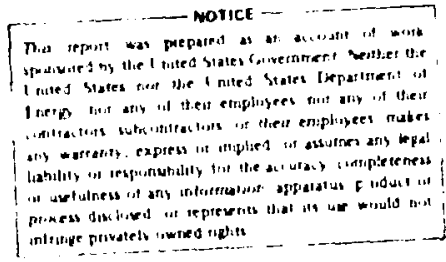

\author{
presented at \\ International Thinkshop-Workshop on \\ "Emerging Concepts of Advanced Nuclear Systems" \\ Institute of Theoretical Physica and Reactor Physics, \\ Universtty of Graz \\ March 29-31, 1978, Graz, Austria
}

The submitted manuscript has been authored under contract EY-76-C-02-0016 with the US Department of Energy. Accordingly, the US Government retains a nonexclusive, royalty-free license to publish or reproduce the published form of this contribution, or allow others to do so, for US Government purposes. 


\author{
ELECTRONUCLEAR FISSILE FUEL PRODUCTION \\ LInear Accelerator Euel Regenerator and Producer \\ LAFR and LAFP \\ Meyer Stelnberg, J. R. Powel1, H. Takahashi, \\ P. Grand, and H. J. C. Kouts \\ Department of Nuclear Energy \\ Brookhaven National Laboratory \\ Upton, New York 11973
}

Apr11 1978

\title{
Abstract
}

A IInear accelerator fuel generator is proposed to enrich naturally ocsurring fertile U-238 or thorium 232 with fissile Pu-239 or U-233 for use in LWR power reactors. High energy proton beams in the range of 1 to $3 \mathrm{GeV}$ energy are made to impinge on a centrally located dispersed liquid lead target producing spallation neutrons which are then absorbed by a surrounding assembly of fabricated LWR fuel elements. The acceleratortarget design is reviewed and a typical fuel cycle system and economic analysis is presented. One $300 \mathrm{MW}$ beam (300 ma-1 GeV) linear accelerator fuel regenerator can provide fuel for 3-1000 MW(e) LWR power reactors over 1ts 30-year lifetime. There is a signizicant saving in natural uranium requirement which is a factor of 4.5 over the present LWR fuel requirement assuming the restraint of no fissile fuel recovery by reprocessing. A modest increase ( $10 \%$ ) in fuel cycle and power production cost is incurred over the present LWR Iuel cycle cost. The linear accelerator fuel regenerator and producer assures a long-term supply of fuel for the LWR power economy even with the restraint if the non-proliferation policy of no reprocessing. It can also supply hot-denatured thortum 0-233 fuel operating in a secured reprocessing fuel center. 
ELECTRONUCLEAR EISSILE FUEL PRODUCTION Linear Accelerator Fuel Regenerator and Producer
LAFR and LAFP

Meyer Ste1nberg, J. R. Powell, H. Takahash1, P. Grand, and H. J. C. Routs Brookhaven National Laboratory

Upton, New York 11973

I. Need for Linear Accelerator Fuel Regenerators and Producers

The nuclear power Industry today is mainly based on light watercooled thermal burner reactors (LWR's) efther of the pressurtzed water-type (PWR) or the boiling water-type (BWR). These reactors have proven performance in providing reliable and economical power and they actually supply almost $10 \%$ of the electric power generated in the US today. The LWR's use low enriched U-235 fuel (LEU). Enrichment is obtained in government-owned gaseous diffusion plants where natural uranium containing $0.7 \% \quad \mathrm{U}-235$ is enriched to approximately 37 U-235 content for use in the LWR's. The enrichment concentration is chosen for safe, economical operation. It takes about 6 tons of natural uranium to produce 1 ton of LEU for use in the LWR power reactors. The depleted 5 tons of uranium contalns about $0.27 \quad 0-235$. The 1 ton of LEU is fabricated into fuel elements and burned in the LWR at a conversion ratio of approximately 0.6 (fissile material produced to fissile material burned) to a total burnup of $30,000 \mathrm{MWD} /$ ton of the LEU. The limitations on burnup in the LWR is controlled by the nuclear reactivity in supporting a self-sustaining chain reaction assembly. The birnup limitation is not due to radiation damage to the cladding 
materlals (zircaloy) of the fuel elements. The apent fuel element upon removal from the LWR contalns roughly $2 \%$ fissile material, about half of which (1\%) is Pu-239 and half (1\%) is the remaining unburned 0-235. Assuming no recovery of this fissile material for reuse by reprocessing, the above described nuclear fuel cycle requires a consumption of 6300 tons of natural uranium for each $1000 \mathrm{MW}(\mathrm{e})$ LWR power reactor over a 30-year production lifetime for the reactor. This includes initial core inventory. In effect only $0.5 \%$ of the natural uranium is ut1lized to make power and the net burnup amounts to only $5000 \mathrm{MWD} / \mathrm{ton}$ of natural uranium. Approximately $30 \%$ less fuel is required if recovery of the Pu-239 is obtained from the spent fuel element by chemical reprocessing. The requirement would then decrease to about 4300 tons of natural uranium,

The natural uranium resource in the US has been estimated to be in the order of $3 \times 10^{6}$ tons. This is for uranium which can be reasonably recovered at a cost of less than $\$ 100 /$ pound of yellow cake $\left(\mathrm{U}_{3} \mathrm{O}_{8}\right)$. This resource then can only support a maximum of $480,000 \mathrm{MW}(e)$ of nuclear power. There are other estimates which fix the uranium reserves at only $1.5 \times 10^{6}$, therefare, only $240,000 \mathrm{MW}(\mathrm{e})$ of nuclear power would be supportable. There are a number of conservative estimates which indicate that the US will need somewhere in the neighborhood of $1,000,000 \mathrm{MW}(e)$ of power at the turn of the century (circa 2000) and that 400 reactors ( $1000 \mathrm{MW}(\mathrm{e})$ each) will share this requirement with other power sources such as coal, ofl, and solar. Based on these values, LWR's supplied by the present nuclear fuel cycle cannot be considered as a long-term solution to the US energy problem. In fact, 
ut111ty executives today are quite concerned about whether to invest in another generation of LWR's. The fast breeder reactor (FBR) has thus been put forward as an absolute necessity in ensuring the longterm establishment of a nuclear fueled econowy.

The fast breeder reactor has a conversion ratio greater than 1.0 so that it allows converting essentlally all the naturally occurring U-238 to fissile material for generating power. With the FBR, the uranium resource can ultinately be extended 200 tives the present value and essentlally an unlimited energy source then becomes avallable. However, a number of drawbacks can be 11sted for FBR's.

1. The fissile materlal concentration being $10 \%$ or more $1 \mathrm{~A} \mathrm{FBR}^{\prime} \mathrm{s}$, is much higher than in LWR's. In fact LWR's must supply the Initial Pu Inventory for the FBR's.

2. A new technology must be adopted for FBR's to replace the present LWR's. The FBR's are elther liquid metal (Na) or gas cooled (He) which implies new and higher unit capital Investments and new safety regulations and precautions.

3. Reprocessing of fuel from the FBR is an absolute necessity.

The present US administration policy on nuclear power is to indefinitely postpone reprocessing as a means towards impeding the possible proliferation of nucle:ar weapons. This policy, at once, further limits the nuclear fuel resource for nuclear power generation and tends to ellminate fast breejier reactor fuel cycles. Studies have, therefore, been Initiated in the US to investigate alternative nuclear fuel cjcles which do not depend on nuclear fuel reprocessing. These are being implemented under the Nuclear Alternatives Systems Assessment Program (NASAP) 
Another series of studies is being conducted by an International group under the title of International Fuel Cycle Evaluation Studtes (INFCE). Some of the fuel cycles proposed to Date as alternatives include the following.

1. Heavy water moderated reactors such as the CANDU reactors which utllize natural uranlum fuel and obtain a net burnup of up as high as 10,000 MWD/ton of natural $\mathrm{U}$. This is almost two times as much as that which can be obtalned with the LEU-LWR fuel cycle. However, the heavy water reactor technology is not readily available in the Us.

2. A number of varlations of heavy water moderated reactors are suggested starting with light water and shifting to heavy water in a spectral shift reactor or a "hand me down cycle",burning the element first in an LWR to $2 \%$ fissile fuel and then in an HWR to less than $1 \%$.

3. Switch to a thorium cycle in an LWR where the conversion ratio can be higher $(20.70)$. The thorium fuel resource is somiwhat higher than the uranium resource in the US. Howevex, in order to utilize thorlum, a means of producling fissile $\mathrm{U}-233$ would be necessary and this requires reprocessing in addition to couverting and breeding.

4. Finally and most important, it is suggested that reprocessing for convertors and breeders be allowed in safeguarded nuclear fuel centers. Although the studies are not yet complete, the apparent conclusion is that without reprocessing, the best burner and convertor fuel cycles can do is stretch the nuclear fuel resource by not more than a factor of two and new HWR technology would have to be introduced. Further stretching In nuclear fuel resources would require safeguarded nuclear fuel reprocessing centers. 
Our proposal of the ilenar accelerator fuel regenerator and fuel producer (LAFR and LAFP alternatively called "electronuclear fuel producer") Introduces a whole new dimension to the LWR fuel cycle economy. Essentially the LAFR and LAFP produce fuel In-gitu with an external sôurce of neutrons. As such, the LAFR can stretch the nuclear fuel resource by a factor of 4.5 or more witksut reprocessing thus providing a longe: term supply of fuel for the LWR. The LAFP with safeguarded reprocessiag can stretch the fuel supply to the ultimate of 200 times the present juist as the FBR does, however, with the notable exception that it maintains the LhR technology and economy in place. The LAFR and LAFP can also produce U-233 from thorium without and with reprocessing, respectively, this opening up thorium as a nuclear fuel resource. Still another opting is possible with the linear accelerator driven raactor (LADR), alth;ugh as will be pointed out lacer, this option is less attractive to utilities because of the complexity of the need of a linear accelerator at each power station.

The option we belleve wost viable and attractive is the Inear accelerator fuel regenerator (LAFR) because (1) it does no: require reprocessing, (2) it stretches the nuclear fuel resource significantly, and (3) it insures a continuing LVR economy. The LAFR is thuis not a power reactor or a breeder. It is a fuel generator and when applied in-situ it is an enricher in the same functional sense as a diffusion flant but without the disadvantage of severely depleting the natural uranium resource. One LAFR can support three or more LWR's and can be considered in the same light as toll enrichment. The fuel producer does not Impose an extension of new technology on the utility operator. The fuel producer is independent of the utility. The fuel producer 
supplies the utility with conventional LWR fuel. More detalled examination of the LAFR and LAFP fuel cycles and economics are made in later sections of this report. The only other external neutron source competitor to the LAFR is the fusion-fission hybrid. In the long run fusion-fission because of the energy economy in producing a neutron could replace the accelerator as a fuel producer. However, the successful demonstration of the feasibility of fusion reaction is still many years away. There are definite operational advantages to the LAFR compared to hybrids. The accelerator fuel producer requires only an extension of present day technology. In this sense the accelerator is unique and really has no near-term competicor. It appears to be the missing link in the LWR nuclear fuel cycle chain.

\section{Accelerator Design}

The ability to confidently utilize linear accelerator technology today stems from a long-term development effort in obtaining reliable linear accelerator machines for use in high energy physics basic researcl. over the past 35 years. In a sense, we are capitalizing on a spin-off of a large developmental investment in basic research instrumentation. The general size and capacity of the LINAC we would need for fuel production is in the range of 1 to $3 \mathrm{GeV}$ protons, and 100-300 ma beam current, or a machine with a capacity in the range of 100 to $500 \mathrm{MW}$ (e) beam capacity. The general concensus among most accelerator designers (2) is that a continuous wave machine can be built today with a reasonable efficiency of $50 \%$, line power input to beam power output. Some even estimate efficlencies as high as $70 \%$. There is no machine operating coday with the specific matching characteristics required. Up to now the 
machines built were research taols; there was no need for a production machine. However, the research machines have approached the required values in a pulsed operation and have become highly rellable and maintainable. Fig. 1 gives a table of parameters of extsting relevant accelerators. It is Interesting to note the LASL-LAMPF approaches the energy required and the CERN-ISR circulates many tImes more current safely (40 amps) than is needed for the LAFR. In addition, there is ongoing development work on Improvements in RF power sources which gives more confidence that a highly efficient and reliable machine $c$ n be constructed today.

III. Neutron Y1eld and Physics

Experimental yield of neutrons per Incident proton on various finite metal targets as a function of the protou energy is given in Fig. 2. Further discussion on jields and energy spectra are given in reference (1). Although deutertum particles may yield $30 \%$ higher neutrons than protons, the Increased cost and complexity of the accelerator for deuterium acceleration more than compensates this advantage; thus protons are preferred. Fig. 3 gives recent Monte Carlo calculations for neutron yields in infinite targets of $\mathrm{Pb}$ and $\mathrm{UO}_{2}$. The effect of water in the target lattice is also shown. The significance of this data is that the yield of neutrons is expected to be at least 30 neutrons/ $1 \mathrm{GeV}$-proton. This does not, however, take into account the additional neutrons produced due to fast fission for neutrons energies $\leq 15 \mathrm{MeV}$. Additional estimates have been made for the fast fission neutron yteld. The values are used to estimace fissile fuel production rate as will be shown later in F1g. 14. We understand a recent measurement on neutron 
yields has been made at Dubna in the Soviat Union by Vesilikov et al (7) with $660 \mathrm{MeV}$ neutrons on a massive $U$ target. The report Indicates a neutron yleld about $50 \%$ higher than values used herein. This would mean that the production rate would be $50 \%$ higher than assumed in this work which would make the economic result look even better than obtalned herein.

IV. Target Design and Engineering

There appears to be a concensus that linear accelerator technology is available today for conatruction of an efficient and reliable continuous wave high current proton accelerator in the $1 \mathrm{GeV}-300 \mathrm{ma}-300 \mathrm{MW}$ power level range. The technology his been developed over the last several decades at the expense of the high energy physics basic research programs In several national and International laboratorles around the world. Howeve:, practically no effort to date has been expended on a suitable target assembly design for production of fissile fuel from natural fertile material.

The criteria for the design of a suitable target assembly is as follows :

1. The proton beam should be in the range of 1 to $3 \mathrm{GeV}$, because of (a) sufficlent proton penetration in a heavy metal target, i.e., in solid lead, $1 \mathrm{GeV}$ protons have a range of only $60 \mathrm{~cm}$ and (b) the yleld of neutrons per proton increases linearly with proton beam energy, i.e., it is about 35 neutron/proton in $\mathrm{Pb}$ at $1 \mathrm{GeV}$, so that for a given production rate of neutrons converted to flssile fuel, 1.e., in the order of 1 ton/year, the current should be in the order of 300 ma. 
2. Since the beam mugt oparate In a vacuum and the target assembly must be cooled under pressure, it is preferrable not to have to maintain a thin window through which the beam must penetrate from the vacuur to the higher pressure. A thin penetrating window 13 necessary to mintwize loss of beam energy over a larger area.

3. Since considerable heat will be developed In ti.: target assembly, it must be sufely and economically cooled. The heat recovered should pl:eferrably be of a high enough quelity to convert to power.

4. The radiation damage to the tertile fuel material must be animized through proper selection of cladding material.

Considering a number of alternate target design assemblies, we have come to the conclusion that the one shown In Figure 4 adequately meets a workable design. The assembly ts deslgned to generate fuel in a PWRtype fuel assembly bundle. The bundles are placed in pressure rubes which surround a central slot throvgh which jets of liquid Pb-Bi metal is passed down along the length of the calandria assembly of pressure tubes. The 1 GeV-300 wa proton beam spreads from the beam transport tubes entering the side of the calandria vessel with no interfering walls and Interacis with the jets or columns of falling liquid lead. Neutrons are spalled and evaporated isotropically from the lead by the high energy protons and the high energy spallation and evaporation neutrons enter through the walls of the pressure tubes and are absorbed by the PWR-type fuel element rods forming fissile Pu-239 from U-238 in-situ. The purpose of the jets is to disperse the dense $\mathrm{Pb}-\mathrm{BI}$ target so as to allow a longer penetration path in the target for the purpose of distributing the neutron flux to a level which will be tolerable from a power density 
point of view. The $\mathrm{Pb}-\mathrm{BI}$ has a vapor pressure of $10^{-4}$ torr at the expected temperature of $300^{\circ} \mathrm{C}$, thus maintaining an adequate low vacuum condition for the proton beam. The $\mathrm{Pb}-\mathrm{BH}$ is collected at the bottom of the vessel and cooled in a separate circuit. A plan view of the arrangement is shown in F1g. 5. Indicating the vacuum vessel boundary and the pressure tube with the internal PWR fuel assemblies. In order to prevent loss of neutrons the outside area of the calandria vessel is covered with a neutron reflector (1.e. graphite) Inciuding top and bottom sections. The assembly should be long enough to accomodate a Eull length PWR bundle (8 ft long).

For cooling purposes, because it is necessary to provide a hard spectrum,steam is used, but since a high heat flux is also expected, wet steam or two-phase evaporative cooling is used. The calandria tubes are pade of zircaloy as is the cladding of the PWR elements. Wet steam prevents corrosion of the zircaloy. Fig. 6 shows a typical PWR-type pressure tube assembly and cooling clrcult. Since top loading of fuel elements is required, a shroud tube and channel surrounding the element must be provided for counterflow of the steam-water coolant. The steam pressure should operate at about 2000 psi and outlet. temperature no higher than about $600^{\circ} \mathrm{F}$. A cross section of the fuel assembly in the shroud tube is shown in F18. 7 .

Another GWR-type target assembly arrangement is shown in Fig. 8. This is of the horizontal pressure tube-type assembly sim.lar in concept to the CANDU reactors. The $P b-B 1$ jets are In the center slot with the pressure tubes surrounding. The fuel elements are inserted horizontally through the pressure tubes. Shorter elements can be used in this arrangement. A plan cross saction of the HWR-type design is shown in Fig. 9. 
The advalulage of this design is that the ls no reentry or shroud cube needed and the flow of coolant is stralosi through from one end to the other. A Jisadvantage is that the tube sheet seal through reflector and shielding end cube sheets must be provided so that the tubes have the capabllity of expanding and contracting due to heating and cooling during startup and shutdown whlle maintalning vacuum.

Neutronfe transport calculations using the neutron cross section libraries meshing with the transport code scheme shown in F1g. 10, was used to determine neutron yleld, flux, burnup, and fissile fuel production. Monte Carlo calculations fur neutrons yleld per GeV proton Impinging on $\mathrm{Pb}$ and $\mathrm{UO}_{2}$ targets are given in Fig. 11. It can be seen that for an infinite target and neglecting high energy fission in $\mathrm{UO}_{2}$ that the spallacion and evaporation yields of neutrons per $1 \mathrm{GeV}$ proton is about the same as a statistical average of about 35 neutrons per proton. By Inserting the water for cooling the target, the neutron yield is lowered somewhat. The values of neutron yields for varlous volume ratio of moderator water to $\mathrm{CO}_{2}$ fuel and water density are given in F1g. 12. The statistical average goes from 27.6 neutron per GeV proton for pressurized water-type configuration (volume ratio $\mathrm{H}_{2} \mathrm{O} / \mathrm{UO}_{2}=2$ and $\mathrm{\rho H}_{2} \mathrm{O}=0.7$ ) to 30.9 for steam sooled tight packed assembly (volume ratio $\mathrm{H}_{2} \mathrm{O} / \mathrm{UO}_{2}=0.5$ and $\mathrm{\rho H}_{2} \mathrm{O}=0.175$ ), which is not a large drop from the infinite metal medium calculations given in the prevlous figure. The general geometry is shown in Fig. 13 for Elux distribution calculations. The calculation of initial yield (no fissile material in fuel) is given in Fig. 14 for various neutron yieids (including fast fission reactions), fertile material (Th or $\mathrm{U}$ cycle) and coolant-type $\left(\mathrm{H}_{2} \mathrm{O}\right.$ or $\left.\mathrm{D}_{2} \mathrm{O}\right)$ and density. The initial yields 
for an acceleracor producing 1 GeV protuns of 300 ma current, vary from a low of 0.31 cons U-233/year for the Th-UO, system to 1.28 tons Pu-239/year for the $\mathrm{UO}_{2}-\mathrm{H}_{2} \mathrm{O}$ syatem. It Is inceresting chat 1 ight water is a beiter coolant than heavy water because of the harder spectrum thus producing wore fast fission neutrons. Furthermore, the themal neutron yield fur U-238 fission is higher than the Th-232, resulting in higher production rates for $\mathrm{Pu}-239$. It should be polnted out that ws fissile fuel builds Into the system or when fuel containing fissile fuel is regenerated, the fissile yield in the highly undermoderated assembly should generate more fuel than when there is no fisgile fuel content because of the multiplication of neutrons. For purposes of the systems and economic evaluation, we have assumed an average production rate of 1.2 metric tons/yr $(1200 \mathrm{~kg} / \mathrm{yr})$.

A parametric study was made of the thermal hydraulics of the system. The heat transfer characteristics of the assembly for the two phase coolant (steam-water) is shown in Fig. 15. The average heat flux of $197,000 \mathrm{BTU} / \mathrm{ft}^{2} / \mathrm{hr}$ is equivalent to about $0.62 \mathrm{MW} / \mathrm{m}^{2}$. For various steam inlet quallties ranging from $30 \%$ steam in water to $70 \%$ steam in water, the average steam concentration ranges from $80 \%$ steam to $92 \%$ steam for coolant velocities ranging from 25 to $75 \mathrm{ft} / \mathrm{sec}$ (and for various fractions of the heat flux), which is reasonable for evaporative cooling purposes while avciting drying out the steam mixture. Wet steam is required to prevent the corrosion of the zircaloy metal cladding on the elements and the pressure tubes.

Fig. 16 indicates the pressure drop range for the two phase flow as a function of inlet steam quality for the same range of parameters given in Fig. 15, range from 5 to 40 psi which is entirely reasonable. The 
pumping power under the highest condition does not e:ceed 30 WW which is snly 5.\% of the power required for the acrelerator (600 MW) and under optimized conditions would be much less.

\section{Fuel Cycle Sygrem}

The conventional LWR nuclear fuel cycle is shown in F1g. 17. It requires 6300 tons of natural uranium for a 30 -year lifecime 1000 MW(e) LWR with $75 \%$ power factor. Without reprocessing 1050 tons of spent fuel containing $\sim 2 \%$ U-235 + Pu-239 must be disposed of. With reprocessing and Pu recycia, the fuel requirement is reduced to $\sim 4300$ tons of natural urantum. The proposed LAFR fuel cycle without reprocessing is shown in Fig. 18. The basis of this fuel cycle is first to (1) head-end enrich natural uranium to $1.6 \% \mathrm{U}-235$, then to (2) Eabricate elements and generate fissile material In-situ in the LAFR to an average of $2.8 \%$ for the initial core Inventory, (3) burn the fuel in an LWR for $30,000 \mathrm{MWD} /$ ton down to 27 fissile material, (4) return fuel and regenerate in the LAFR back to $3.2 \%$, (5) further burn another $30,000 \mathrm{MWD} /$ ton in the LWR, and (6) finally discard the $2 \%$ spent fuel after the second LWR burn cycle. There are two reasons for head-end isotope enrichment: (1) it makes up Inventory lost in the spent fuel, (2) it is more economical than building up initial core inventory from natural uranium in the LAFR, and (3) It takes less time to build up LWR inventory (1.e., It would take 1 LAFR at least two years to build up inventory of 2.4 tons for 1 LWR core loading). With 1.67 enrichment, it takes less than 1 year to provide the IWR inventory. The cycle assumes a $300 \mathrm{HW}$ beam LAFR producing $1200 \mathrm{~kg} / \mathrm{yr}(1.2 \mathrm{MT} / \mathrm{yr}$ ) of fissile Pu-239. Two burn cycles for a total of $60,000 \mathrm{MWD} /$ ton is possible today with conventional zircaloy clad $\mathrm{VO}_{2}$ fuel elements since burnup exceeding this value has been obtained in tests in existing water reactors. Zircaloy materlal damage saturates 
at 10,000 Mwo/ton and further burnup does not alter the physlcal and chemlcal properties of zlrcaloy. (4) The 30-year lifetime natural U fuel requirement for this cycle is 1400 tons/day which $1 \mathrm{~s} 4.5$ times less than the 6300 tons/day presently required. This, therefore, yields a substantial improvement in utilization of the nuclear fuel resource. The calculation of fuel requirement is shown in Fig. 19. A shuffling of fuel between the LWR and LAFR is necessary in three zones. The average Initial feed enrichment is $2.8 \%$. Only one example set is given in the figure but the LAF? actually supplies three LWR's. In the equilibrium mode, fuel goes into the conventional LWR at $3.2 \%$, progresses through the three zones after three years at $10,000 \mathrm{MWD} / \mathrm{ton} / \mathrm{yr}$ and comes out at $2 \%$ for regeneration. The intial $1.6 \%$ enrlched fuel which precedes the LAFR actually provides inventory for the LWR every 6 years because of the total burnup of 60,000 MWD/ton. The maximum equivalent burnup stress due to the regenerator is 6,000 MW/ton which is not more than $20 \%$ of the LWR burn cycles. This is a maximum burnup based on generating no more heat in the target than is necessary to provide power to the accelerator to make the system selfsufficlent. It may be more economici 1 and less stressful not to generate that much power and to purchase outslde power for running the accelerator. Optimization studies need to be formed on this point. Another interesting and attractive observation of this fuel cycle is that the isotope enrichment plant requirement to fuel LWR's is drastically reduced as the enrichment decreases. A factor of 6 is needed in natural fuel when enriching from $0.7 \%$ to $3.2 \%$, while there is only a factor of 2.8 needed in enriching from $0.7 \%$ to $1.6 \%$. As will be shown later, the capactty and separative work unit (SWU's) requirements are considerably reduced and thus the 
fuel cycle cost is reduced accordingly. Another point for this fuel cycle is that because of the 2 burn cycles there 18 only 500 tons of spent fuel for disposal or half the amount of the conventlonal LWR cycle. However, the spent fuel wtll contaln mostly Pu-239 Instead of half Pu-239 and half U-235 nf the contained $2 \%$ fissile material.

A general calculation to indicate the effec= of additional burn cycles is shown in F1g. 20. Beyond 2 burn cycles the incremental gain In resource decreases, 1.e., 2 burn cycles finproves the resource 4.5 times and 5 burnup cycles increase it further by a factor of 2.5 to 11.3 times. Although significant, the stress at $150,000 \mathrm{MWD} /$ ton on tha fuel element material may not be achlevable. Another point is that even at 1 cycle, the gain is a factor of 2.3 which is gignificant even without stressing the element beyond today's conventional burnup.

Figure 21 traces through the entire U-Pu-239 fuel cycle economy for 1 LAFR supporting 3 LWR's. In this case, we have assumed a maximum thermal power generation In the target assembly of $1800 \mathrm{MW}(t)$ (300 MW(t) direct beam deposition in the lead target and $1500 \mathrm{MW}(t)$ in the surrounding blanket due to fast fission multiplication). This energy would be sufficient to generate $600 \mathrm{MW}(e)$ at $33 \%$ power cycle efficiency to feed the accelerator power supply with a $50 \%$ power input to beam power output efficiency. The LAFR then becomes self-sufficient in power. Definitive design calculations are yet to be performed concerning the power cycle. Optimization and economic studies may Indicate that it would be more desirable to generate less power in the target and purchase deficit power from an outside power source. The tradeoff between internal power generation and external purchasing of power, however, should not 
effect the ecoromic comparison signtflcautly.

VI. Economic Analysis

A first-order comparative economic analysis is presented in the following. Capital costs for the 1 LAFR/3-1000 MW(e) LWR's system is given In Figure 22. Since detalled estimates were not made, direct unit costs were used based on recent studies. The LINAC accelerator unft cost was assumed to be $\$ 600 / K W(e)$ of power input based on a detalled parametric study by P. Grand. (3) The target reactor assembly was assumed to be equivalent to an LWR at $\$ 600 / \mathrm{KW}(\mathrm{e})$ based on LWR cost studies by Bechtel. (5) In some respects, the target assemly is less complex than an LWR. It is a subcritical assembly and has no control rods. On the other ahnd, it uses a liquid metal lead target and two-phase steam-water cooling. These were assumed as tradeoffs and the unit cost equivalent to an LWR is thus justified. The direct cost for the LAFR complex thus amounts to $\$ 720 \times 10^{6}$. Adding the 3-1000 MW(e) LWR's brings the total Investment for the system to $\$ 2,520 \times 10^{6}$ or a unit capital cost of $\$ 840 / \mathrm{KW}(\mathrm{e})$ of net power output. This value is $40 \%$ higher than the conventional $\$ 600 / \mathrm{KW}(\mathrm{e})$ for LWR's and is the same range as first projected for the fast breeder reactor (FBR) capital cost. As will be shown later, this increased capital investment is traded off against lower fuel cost as in the case which is made for justifying FBR economics.

The power generation cost is shown in Fig. 23. The 1 LAFR-3 LWR cost is compared to the conventional LWR. There is an $83 \%$ increase over base capital cost for completion and financing for operation in 1986. The reason for this large increment is due to financing charges during the years of construction and escalation at $7 \%$ per annum, usually assumed. 
The power generation cost is calculated averaged over the first 10 years of operation. As shown, capital charges ( $15 \%$ and $70 \%$ plant factor) are 407 higher for the LAFR syotem, however, fuel cycle cost is one third that of the LWR. An Increment In operation and malntenance costs was assumed for the LAFR over the LWR due to the need to operate the LAFR. The total operating cost of $46.1 \mathrm{mills} / \mathrm{kwh}(\mathrm{e})$ for the LAFR-3 LiWR system is thus only $67 \mathrm{higher}$ than the $43.5 \mathrm{mills} / \mathrm{kwh}(\mathrm{e})$ estimated for the conventlonal LWR. Thus, the LAFR-3 LWR system is shown to be within reasonable competitive value with LWR costs today. The Increased capital cost is traded off for decreased fuel cost, but much more significantly this is accomplished with a 4.5-fold Increase in the nuclear fuel resource utilization.

A detalled breakdown of the fue: cycle is shown in Fig. 24. Escalation is assumed starting in 1977 to operation in 1986. Yellow cake and $\mathrm{UF}_{6}$ conversion decreases 4.5 times because of the 4.5 -fold decrease in natural uranium requirement and handling. The enrichment SwU requirements decreases first 4.5 times because of the lower throughput and another 2 times because of the lower enrichment (1.6\% instead of $3.2 \%$ ) which yle1d a total 9-fold decrement in enrlchment cost. The remaining parts of the fuel cycle, 1.e., fabrication, storage, carrying charges and transportation only declines 2 times because there is only a 2-fold decrease in fuel handling because of the 2-cycle burn. The overall 1 LAFR-3 LWR fuel cycle cost thus comes out to be about one third that of the conventional LWR fuel cycle cost. 
It is Luteresting to poinc out that a recent Sargent and Lundy ${ }^{(6)}$ estimate for LWR's operational in 1990 escalated and averaged for 30 year operation to the year 2020 estimates a total power generation cost of 80 mills/kwh(e) and a fuel cycle cost of 27 mills/kwh(e) which is about double the costs estimated above. The largest factor in the fuel cycle cost becomes the cost of yellow cake whIch reaches $\$ 100 / 1 b \quad \mathrm{U}_{3} \mathrm{O}_{8}$ in 1990 and escalates from there, reflecting the continued severe shortage nf uranium reserves.

Another method of comparing fuel cycle cost is given in Fig. 25, estimating the cost of generating a gram of fissile Pu-239 directly In the LAFR alone. The $\$ 720 \times 10^{6}$ capital Investment in LAFR is excalated to $\$ 1,320 \times 10^{6}$ for 1986 operation. Adding fuel cycle and O\&M to the depreciation on the capital, brings the unft production cost to $\$ 257.00 / \mathrm{gm}$ of fissile material produced (Pu-239). This also represents the unit cost of fissile material consumed in the LWR's and made up in the LAFR.

The equivalent cost of fabricated LEU-LWR fuel today for 1986 operation is $\$ 242.00 / \mathrm{gm}$ of fissile material consumed (U-235 and Pu-239). At a conversion ratio of 0.6 the amount of power produced per gram of fissile fuel consumed is $18,200 \mathrm{kwh}(\mathrm{e}) / \mathrm{gm}$. Based on the actual cost of initlally enriched $\mathrm{U}-235$, the cost is calculated to be $\$ 96.00 / \mathrm{gm}$ of U-235 contained in the element. However, when no flssile material is recovered because the spent fuel is thrown away and is not reprocessed, the amount actually burned is only $40 z$ of that originally put into the reactor so that the effective charge is 2.5 times this amount for the material actually burned or $\$ 242.00 / \mathrm{gm}$. Again, on this basis the LAFR 
fuisl cost is within $10 \%$ of the LWR cost and thus is reasonably competitive, A listing of the conclusions from the economic estimates is given in Fig, 26. By invoking the thorlum and LWR cycles, the LAFR economics Improves significantly.

F1g. 27 shows a conversion ratio correlation when going from fuel cycles of $\mathrm{U}-23 \mathrm{~J}-\mathrm{UO}_{2}$ to $\mathrm{Pu}-239-\mathrm{UO}_{2}$ to $\mathrm{U}-233-\mathrm{ThO}_{2}$ to $\mathrm{U}-233-\mathrm{ThO}_{2}$ (HWR moderated), the conversion ratio increases from 0.6 to 0.73 to 0.9 and the number of reactors that can be supported increases inversely proportional to one minus the conversion ratio $(1-c . r$.$) . Thus in F18. 29, It is seen that$ for U-235-LWR, 3.4 LWR's can be supported; for U-233 and Pu-239-LWR, 5.0 LWR's can be supported and for U-233-ThO ${ }_{2}-\mathrm{HWR}, 13.6 \mathrm{HWR}$ 's can be supported. The resource multiplication goes from 4.5 times to 6.1 times to 18.0 times without reprocessing. With jeprocessing, all the resource can be utilized for an increase of 200 times that of the present fuel cycle resource utilization. The power production cost decreases from 44.3 to 39.7 to $35.9 \mathrm{mills} / \mathrm{kwh}(\mathrm{e})$. The latter does not decrease as much as one would expect because of the additional cost of heavy water $\left(D_{2} 0\right)$.

For a more proliferation-resistant thorium fuel cycle, it is suggested to denature the U-233 bred fissile material with the addition of natural or depleted $\mathrm{U}-238$. In this manner, the U-233 is isotopically mixed with U-238 making it Impossible to separate by chemical means when considering fuel reprocessing. It is suggested that about 20 to 307 of $\mathrm{U}-238$ be mixed with Th-232, splked with U-233 in a safeguarded fuel center which is then fabricated into LWR fuel. The LAFR and LAFP fits into this scheme very well in that, if natural uranium is enriched to approximately $7 \%$ in an enrichment plant as shown in Fig. 29 and is 
diluted with natural thorium 232 in a fuel fabrication plant with a proportion of $70 \%$ Th to $30 \% \mathrm{U}$, the fuel element produced w111 have about 32 U-235 ready for an LWR. The element after one cycle burnup can be regenerated in an IAFR to boost the fissile fuel content now in terms of $\mathrm{U}-233$ back to 32 or more which can then be further burned up. On reaching the ilmits of regeneration after 2 or more cycles, i:he element can then be sent to a secured fuel reprocessing center to separate out the flssion products and the fuel then refabricated and regenerated to LWR quallty. In this manner, the fuel can be totally burned up. The sycle is doubly-proliferation resistant since $1 t$ produces radioactively "hot" in addilion to denatured fuel. The reason for the secure reprocessing area is that a small amount of Pu-239 (compared to present fuel cycle) is formed from the U-238 which is chemically separable. It should be pointed out here that if reprocessing is allowed, fissile Pu-239 can be read1ly produced from abundant sources of read1ly avallable depleted natural U-238 with the use of the LAFP.

An estimat of the effect of denatured systems on the US nuclear growth patterns has been made by the nuclear energy office of DOE and is graphically produced In FIg. 30. Essentlally, it says that with a once-through LWR throwaway cycle and a fuel resource of $\$ 3 \times 10^{6}$ tons of natural 0 that only 400-1000 MW(e) LWR's can be supported through the year 2010 before a $\mathrm{U}$ shortage developes. By recycling $\mathrm{Pu}$ and converting to thorium in a convertor and finally going to a Pu/U/Th FBR with secured reprocessing the LWR fuel can be increasingly extended but that not much more than one LWR reactor can be fueled by one FBR. Th1s 
is symptomatic of EBR's since they essentially replace themselves with 15 to 30 year doubling times. This points up the adage that "fast breeders do not breed fast".

Performing the same analysis but now Introducing the LAFR and the LAFB into the fuel cycle, as shown in FIg. 31, the 1 LAFR-3 LWR system can ext.end the fuel supply to support 700-1000 MW(e) reactors at the growth rate expected to the year 2030 and this is based on the more conservative estimate of $1.5 \times 10^{6} \mathrm{MT}$ of uranium rather than the $3.0 \times 10^{6} \mathrm{MT}$ assumed by the DOE in FIg. 30. With the 1 LAFR-5 LWR denacured thorfum cycle and finally the LAFP with reprocessing, the utilization can be stretched into the long term future similar to the FBR with fuel reprocessing.

A comparison is now made between conventional, internal neutron (LWR and LPBR) and non-conventional external neutron (hybrid and accelerator LAFR and LAFP) sources as shown in Fig. 32. A billion dollar U-235 enrichment plant buys about $1.5 \times 10^{6}$ swU's and can support about 10-15 LWR's requiring 40,000 to $60,000 \mathrm{MT}$ of natural fertile fuel depending on whether reprocessing is used or not. There is little flextbility in this fuel cycle. The urantum is depleted and the resource is severely limited. A $1000 \mathrm{MW}(\mathrm{e})-\mathrm{LWR}$ costs $\$ 1$ billion and roughly uses 6000 tons of uranium without reprocessing and 4000 tons with reprocessing as stated earlier. The net addition of U-235 or Pu-239 to make up for burnup is about $350 \mathrm{~kg} / \mathrm{yr}$ of fissile material. The LWR is severely limited in resource; it cannot support any other LWR. The LMFBR costs $\$ 1.4$ billion and depending on doubling time it can produce enough excess fuel to just about support one LWR. Without 
reprocessing, the LMFBR calnot function at all. Thus, the LMFBR is limited for useful support of any satellite LKR's.

The fusion-fisston hybrid is estimated to cost $\$ 3.7 \times 10^{9}$ billion and produces 1.5 MT of fissile material while developing $500 \mathrm{MW(e)}$ of , power. Using the slightly enriched (1.6\% v-235) fuel cycle discussed above, the hybrid can support five LWR's at a reduced resource requirement of 2100 tons of uranium over the 30-ytar lifetime while with reprocessing it essentially can burn up all the fuel. On a 0.9 conversion ratio thorium cycle, the hybrid can support $20 \mathrm{GWR}^{\prime} \mathrm{s}$ and there are essentially no limitations on the fuel cycle. With the sccelerator, LAFR and LAFP, an invesment of $\$ 1.3$ bilition produces $1.0 \mathrm{MT}$ of f1ssile fuel which supports three LWR's or on the Th-U cycle 12 LWR's with a much reduced fuel resource requirement and an unlimited flexibility in fuel cycle. The essential differences between the hybrid and the accelerator is that the hybrid capital investment is estimated to be twice as great as the accelerator for the same fissile fuel production capacity and secondly, the hybrid needs feastbility demonstration, while the accelerator is here and can be raliably bullt today with only an extension of present day technology.

Still another comparison of long-term fissile fuel production systems is made In Fig. 33. In this figure, the FBR/LFR system is compared to che LAFR/LWR and the hybrid/LWR system in terms of total system capital investment and new technology investment (NTI) as well as R\&D cost and commercial date of Introduction. A constant total of 500-1000 MW(e) nuclear power economy is assumed for this comparison. The FBR/LWR requires a $\$ 600$ billion investment with more than half, $\$ 350$ billion, in new 
technology capital investment In LMPBR's. Since a good deal of R\&D has already gone Into LMFBR, it is estimsted that only an additional $\$ 3$ billion would be required to bring it to comerclalization by about 1990 or somewhat thereafter. The LAFR/LWR system would require $\$ 630$ to $\$ 725$ billion total capital with $\$ 130$ to $\$ 225$ b1l11on Investment in the new technology of accelerator fuel regenerators and froducers, depending on whether a $\mathrm{U} / \mathrm{Pu}$ or a $\mathrm{Th} / \mathrm{U}$ cycle is used. Since much effort has already gone Into development of accelerators that has been paid for by the high energy physics basic research program, it is estimated that oniy another $\$ 3$ billion would be required to bring it to commercialization, only a few years later than the LMPBR, say about 1995 or soon thereafter. In the hybrid/LWR system, the total investment cost ranges from $\$ 670$ to $\$ 780$ billion with new fuston-fission technology investment of $\$ 2 \mathrm{CO}$ to $\$ 330$ billion and would require much more R\&D to bring to commercialization, say $\$ 15$ billion and then it is kighly questionable how long the development would take to become available after the year 2000, if ever. Undoubtedly from all viewpoints, ...e. technology availability, lower cost of new technology extension of fuel resource utilization, the LAFR/LWR system beats the FBR and the hybrid.

vII. Conclusions

Fig. 34 summarizes the unique features and advantages of the linear accelerator fuel regenerator and fuel producer. The last item has not beem mentioned heretofore but can be of utmost Importance. Just as accelerators can transmute fertile material into fissile material through neutron reactions, so It should be possible to transmute very longlived residual fissile material and transurantcs into shorter lived 
ant stable elements. It may also be possible to transmute long-ifved Elssion products (1.e., 30-year half-11fe Cs-137 and Sr-90 to shorter lived and stable isotopes. This is a subfect outside the scope of this paper but is Important to investigate.

Finally, FIg. 35 estimates the schedule and R\&D costs required for commercial implementation in terms of 1978 dollars. The progrim starts with neutron yleld and kinetics studies probably at existing accelerator site (1.e., Los Alamos, Meson factor (LAMFP)) and progresses through accelerator and target development to a small-scale p1lot plant, to a full-acale prototype and finally, near the turn of the century, to commercial plant operation. The entire research and development cost should total in the range of 3 to 4 billion dollars.

The accelerator fuel generator or electronuclear breeding can be considered to be the missing link in the thermal LFR and HWR nuclear power reactor economy and is eminently worthwhile pursuing to its fullscale development. 


\section{References}

1. M. Steinberg, et al. Linear Accelerator-Breeder (LAB) A Preliminary Analygis and Proposal, BNL 50592 (November 10, 1976).

2. H. J. C. Kouts and M. Steinberg. "Proceedings oi an Information MeetIng on Accelerator BreedIng", ERDA/Conf. 770107 (January 18-19, 1977).

3. P. Grand, BNL, privace communication (Apr11 1977).

4. R. Saybolt, Westiaghouse Corp., private communication (January 1978).

5. Bechtel Corp., ANS Industry Report, 1976-7 (February 1977).

6. Sargent and Lundy, private communication (March 1978).

7. S. Schriber, private communication at meeting on Emerging Concepts In Advanced Nuclear Systems, Graz, Aus trla (March 29-31, 1978). 


\section{FIGURE 1}

PARAMU.TERS OF EXISTIHIG RLLLVANT ACCFLERATORS

\begin{tabular}{|c|c|c|c|c|c|c|}
\hline \multicolumn{2}{|c|}{ ACCELERATOR } & \multirow{2}{*}{$\begin{array}{l}\text { I0N } \\
\text { JYYPt. }\end{array}$} & \multirow{2}{*}{$\begin{array}{l}\operatorname{Enn} x \\
\text { PALK }\end{array}$} & \multirow{2}{*}{ 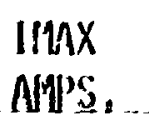 } & \multirow{2}{*}{$\begin{array}{l}\text { DUETY } \\
\text { FACIOR }\end{array}$} & \multirow{2}{*}{ SIATUS } \\
\hline LALRRATRPY & IYPE & & & & & \\
\hline LASL-LNMPF & LINAC & PROTOR & 30) & 0.020 & $12 \%$ & OP \\
\hline LBL-IIILAC & LIHAC & $11.10 \mathrm{NS}$ & 10/illicL. & - & $50 \%$ & OP \\
\hline Bill-NGS & LINAC & PROTON & 200 & 0.2 & $0.5 \%$ & OP \\
\hline FHIAL & LINAC & PROTON & 200 & 0.3 & $0.2 \%$ & OP \\
\hline UEDL-HFNS & LIIAAC & DEUTT. & 35 & 0.1 & $100.0 \%$ & PROP \\
\hline CERN-ISR & $\begin{array}{l}\text { STIRRAGE } \\
\text { RIMUSS }\end{array}$ & PROTOII & $3 \times 10^{4}$ & 40.0 & - & OP \\
\hline BSWL-ISA & $\begin{array}{l}\text { STORAGE } \\
\text { ACCELER }\end{array}$ & $R_{R}^{\text {PROTON }}$ & $4 \times 10^{5}$ & 6.0 & - & PROP \\
\hline
\end{tabular}




\section{FIGURE 2}

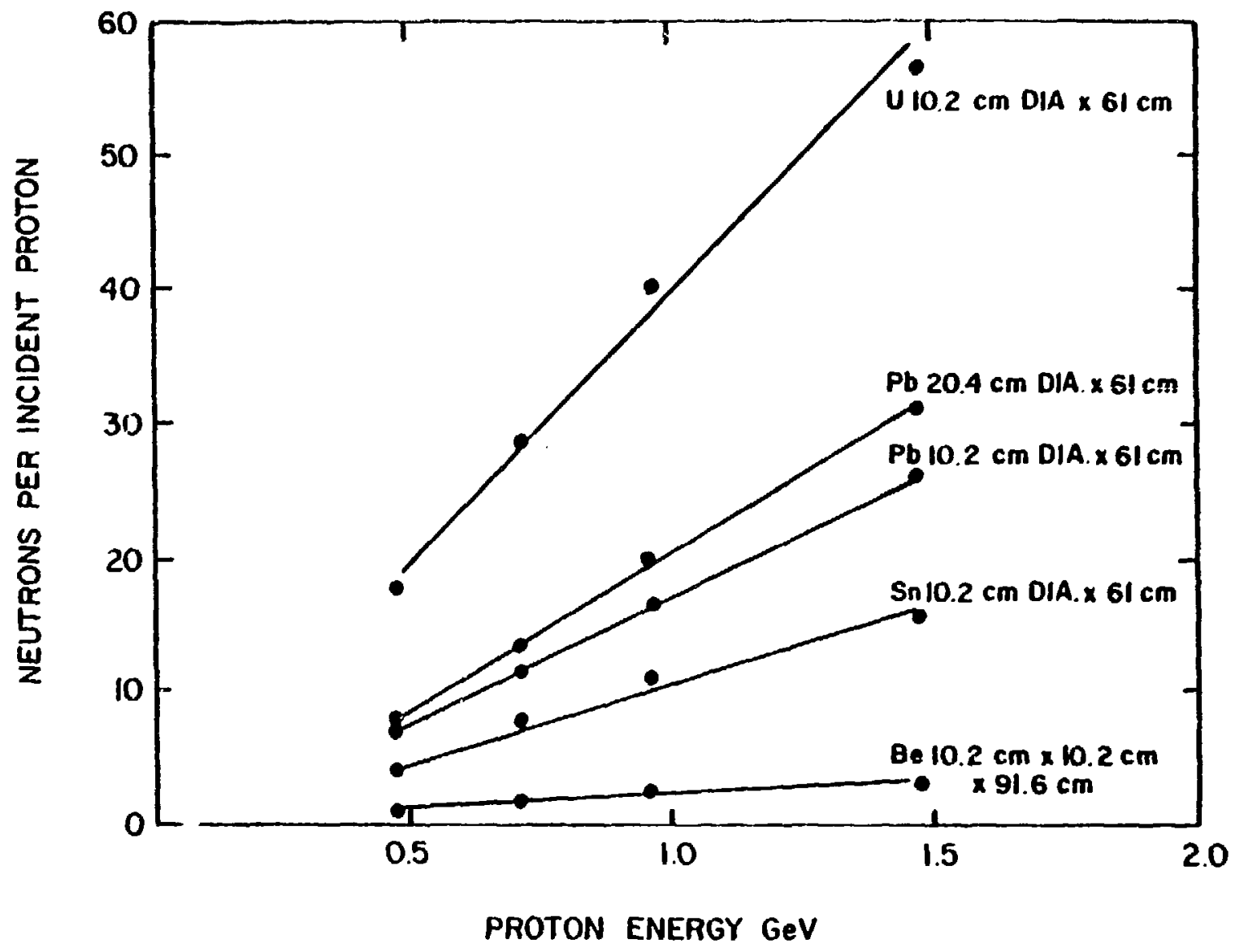

EXPERIMENT YIELD OF NEUTRONS BY BOMBARDMENT OF A HEAVY METAL TARGET WITH HIGH ENERGY PROTONS 


\section{FIGURE 3}

\section{MNNTE CARLO CALCULAIIINAS}

FOR PB ANID $\mathrm{HO}_{2}$

SEUTTRONS PRODUCED BY REACIIONS OF GREATER TIIAN

OR EMUAL TO 15 MEV EXCITATION ENERGY

HEUTRONS/1 GEV PROTON

\section{TARGET MAT.}

PB

$\mathrm{UO}_{2}$

$1.4 \mathrm{H}_{2} \mathrm{O} / \mathrm{UO}_{2}$ EFFECTIVE VOL. RAT 10

$0.7 \mathrm{H}_{2} \mathrm{n}$

$0.17 "$
AVER. YIELD*

35

35

28

29

30

INFINITE MEDIUM, 1 GEV PROTON INJECTED INTO CENTER

"does not include fission neutrons < 15 MeV. 
FIGURE 4

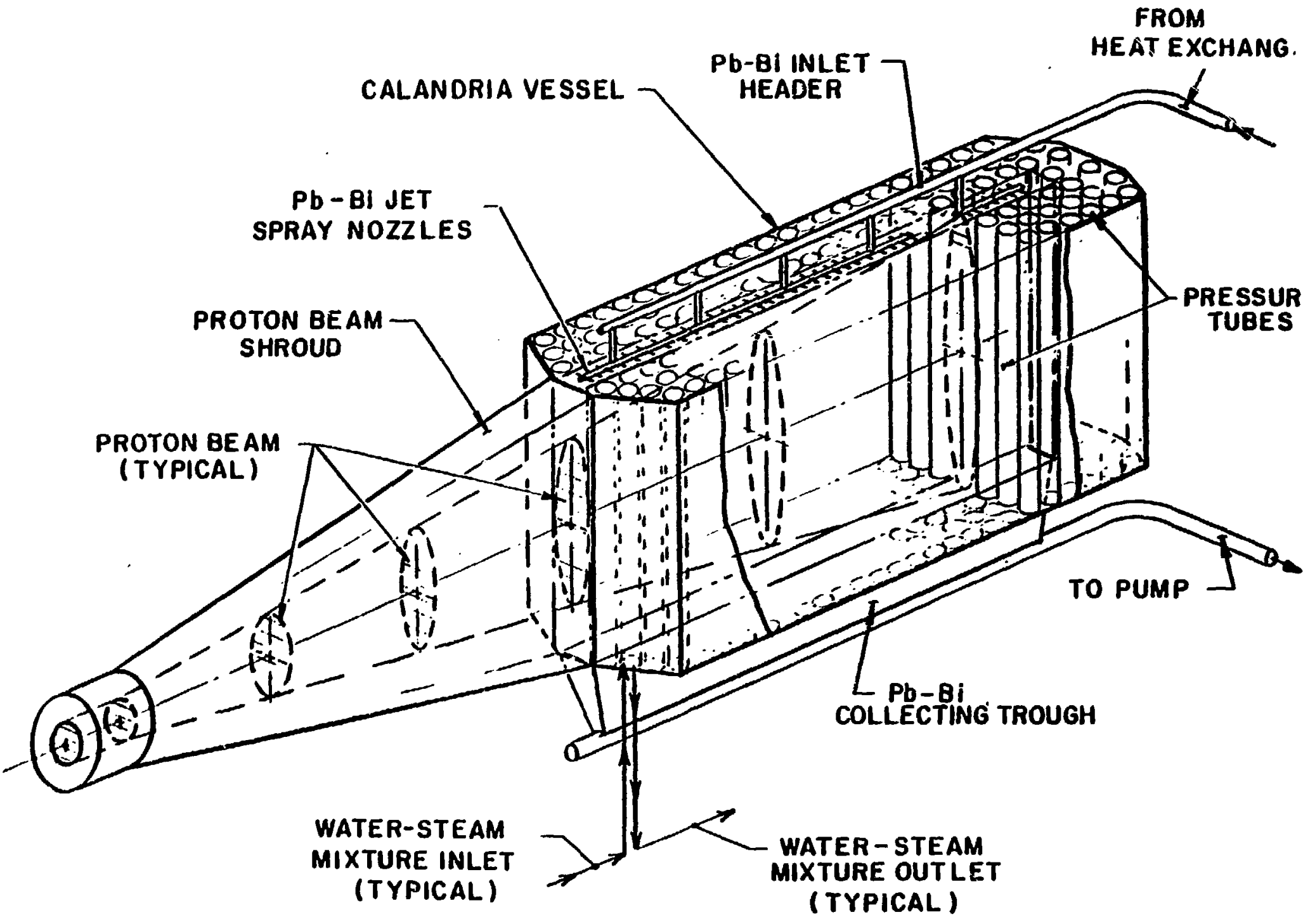


FIGURE 5

\section{$36 \mathrm{~cm}$ TRIANGULAR PITCH}

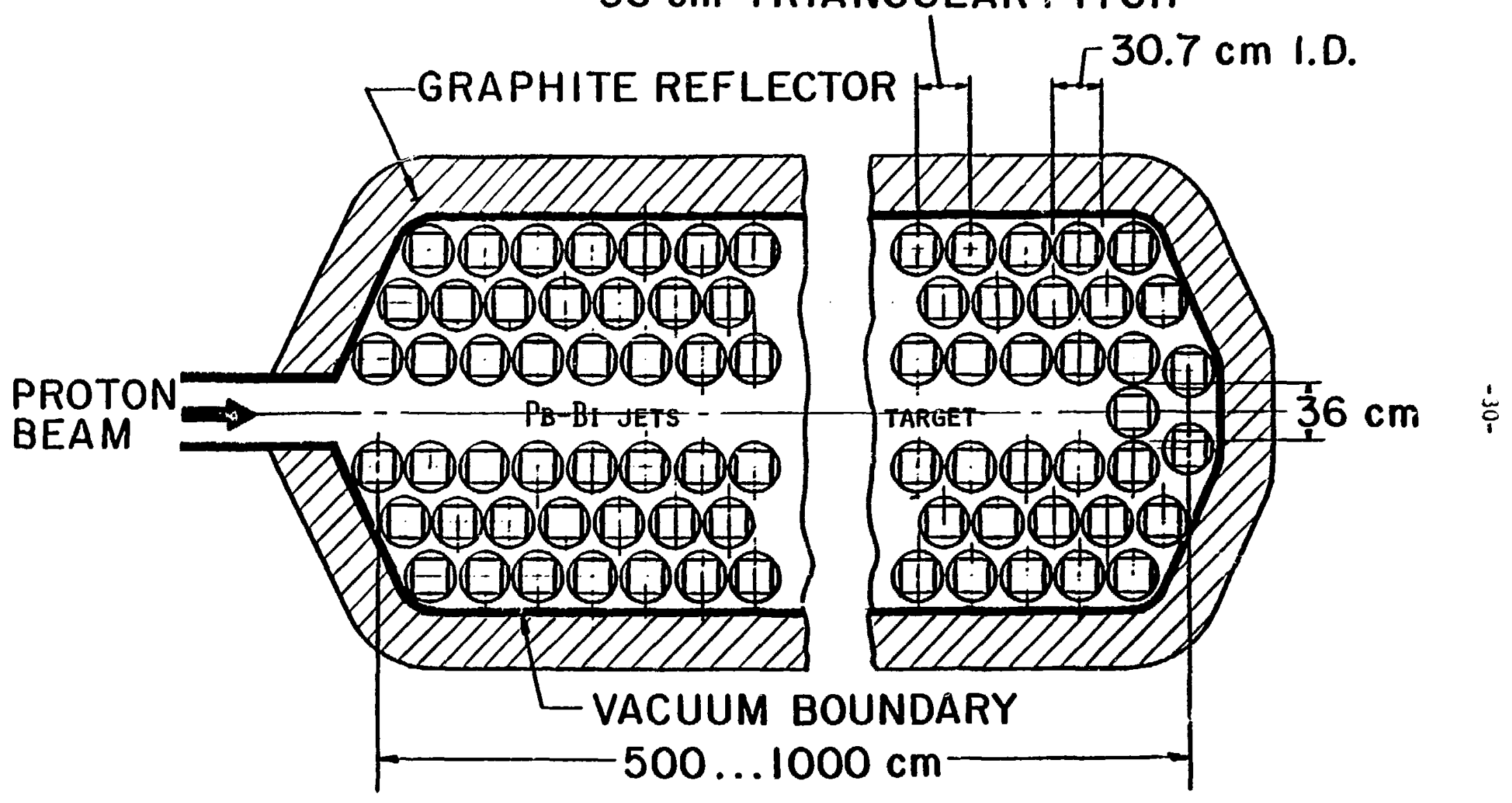


FIGURE 6

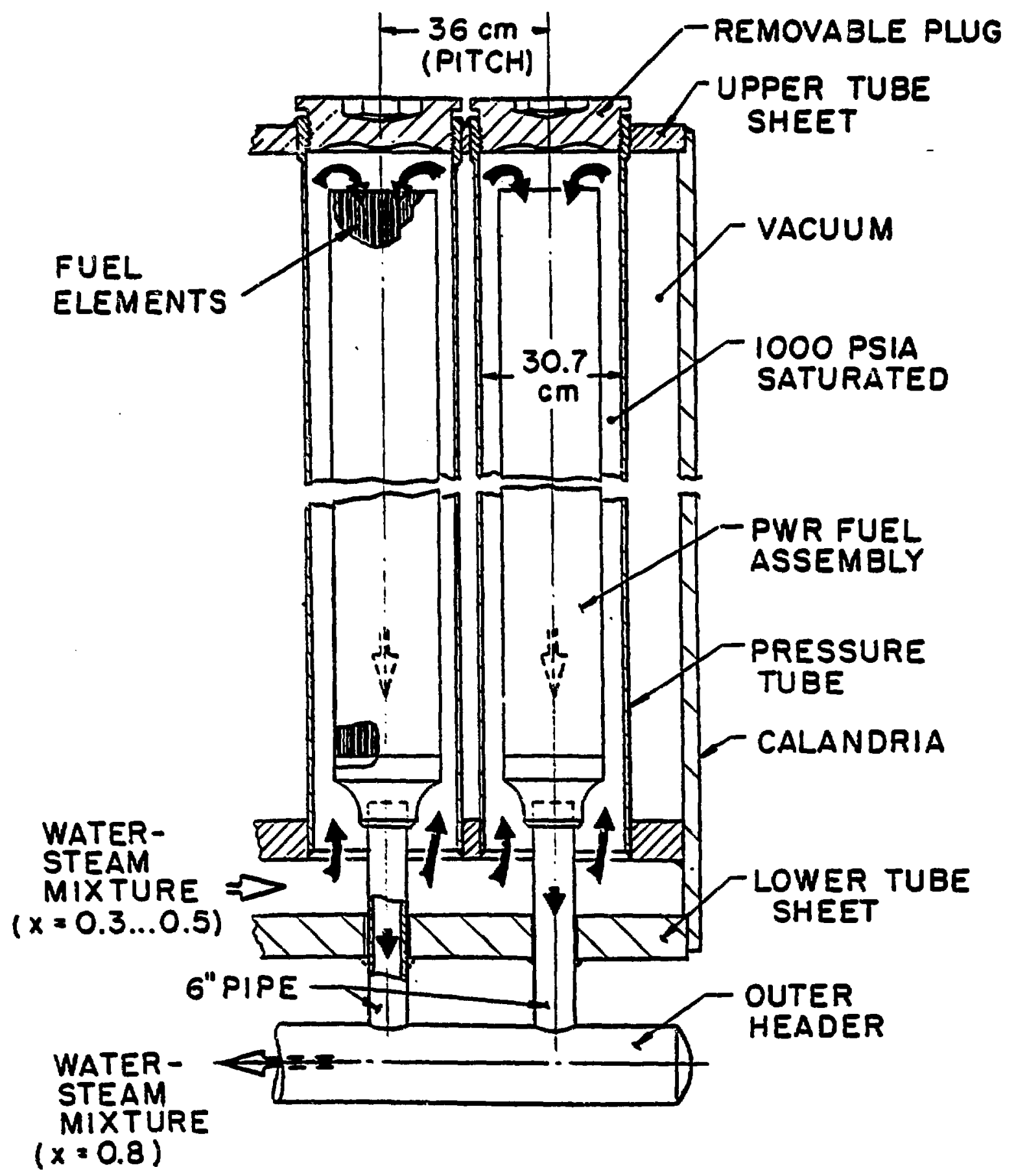


FIGURE 7

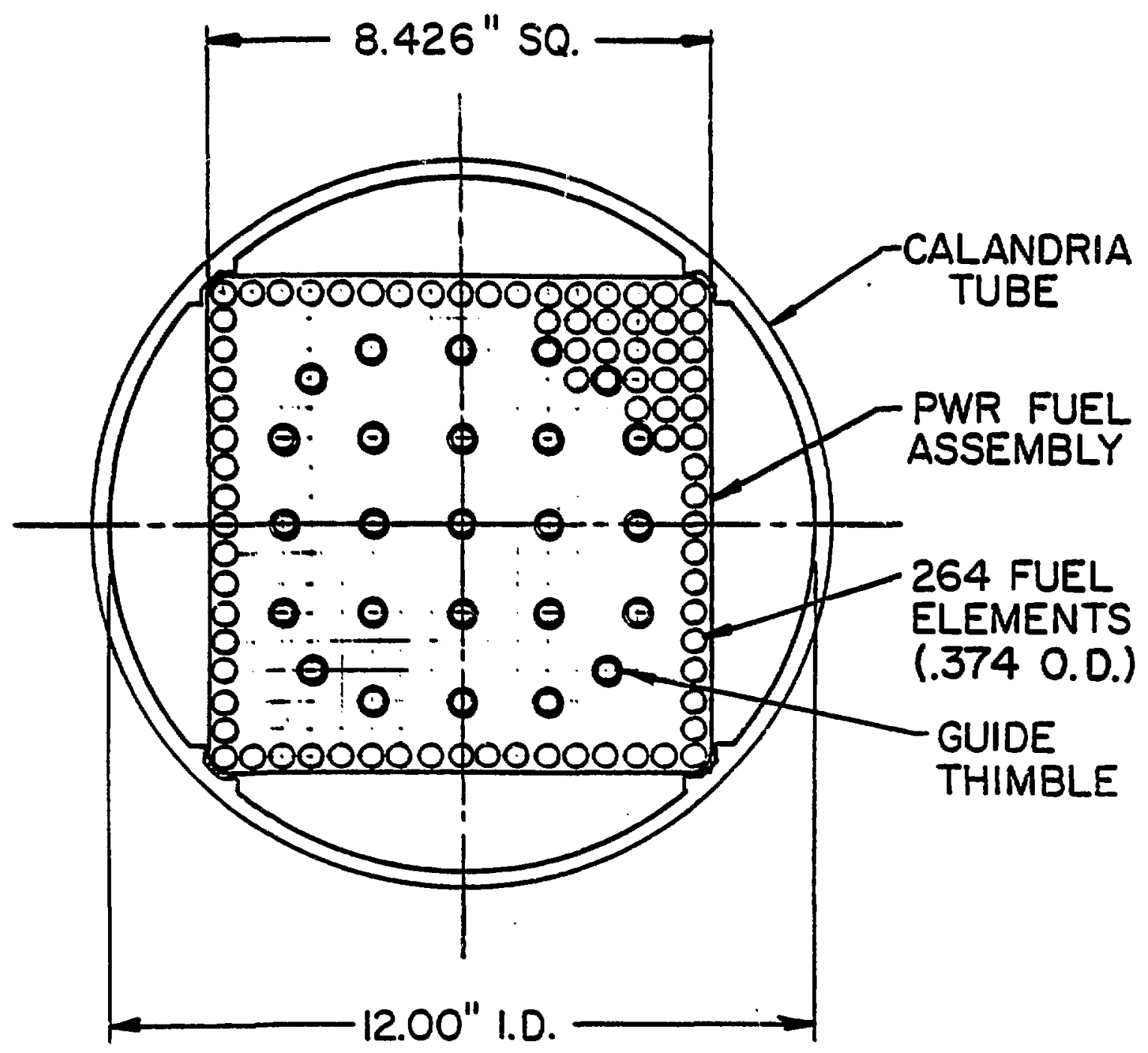

NOTE: THE GUIDE THIMBLES ACCOMODATE:THE PWR CONTROL CLUSTER ELEMENT

PWR PRESSURE TUBE ASSEMBLY CROSS SECTION 


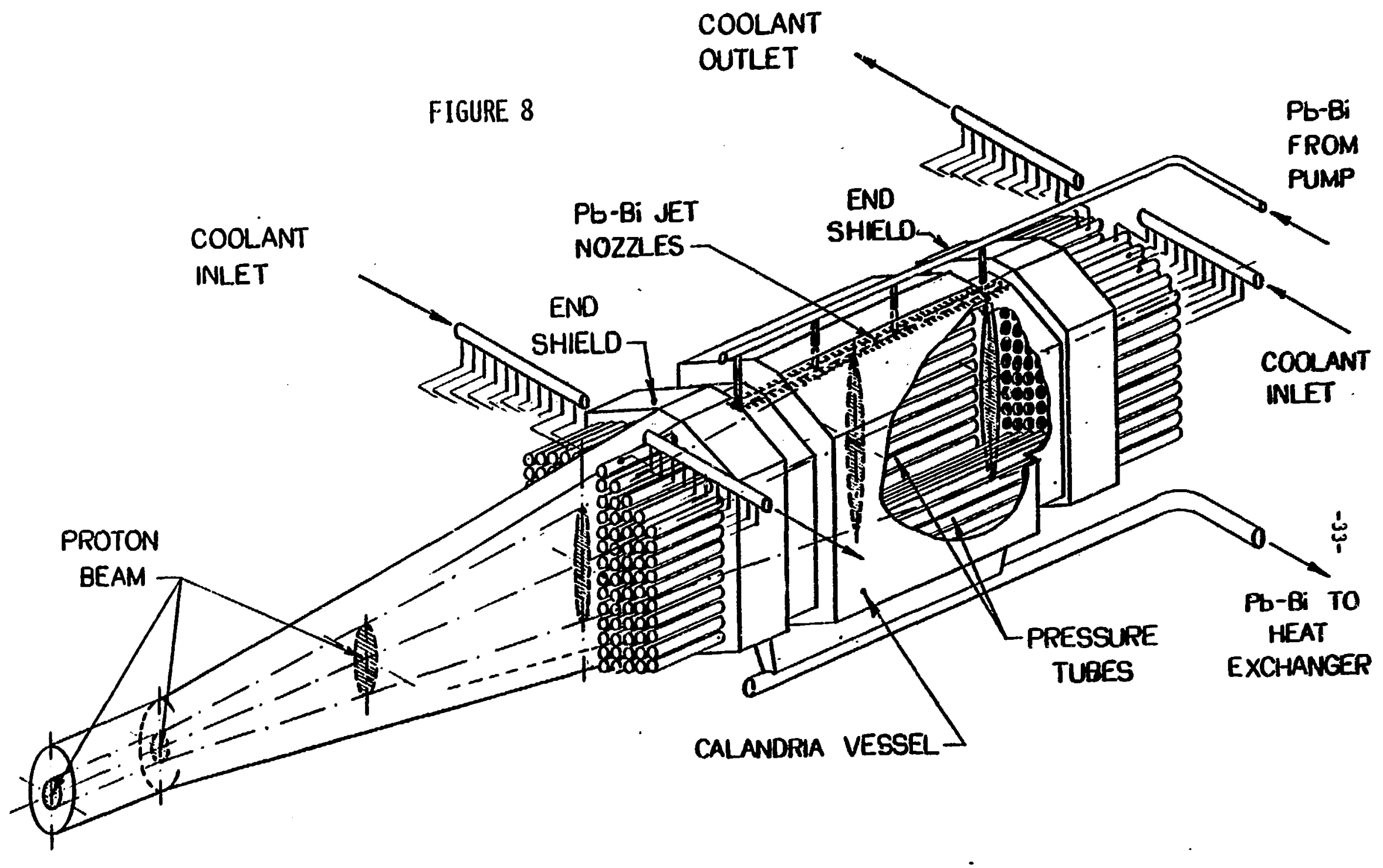

HWR TYPE TARGET ASSEMBLY . 


\section{FIGURE 9}

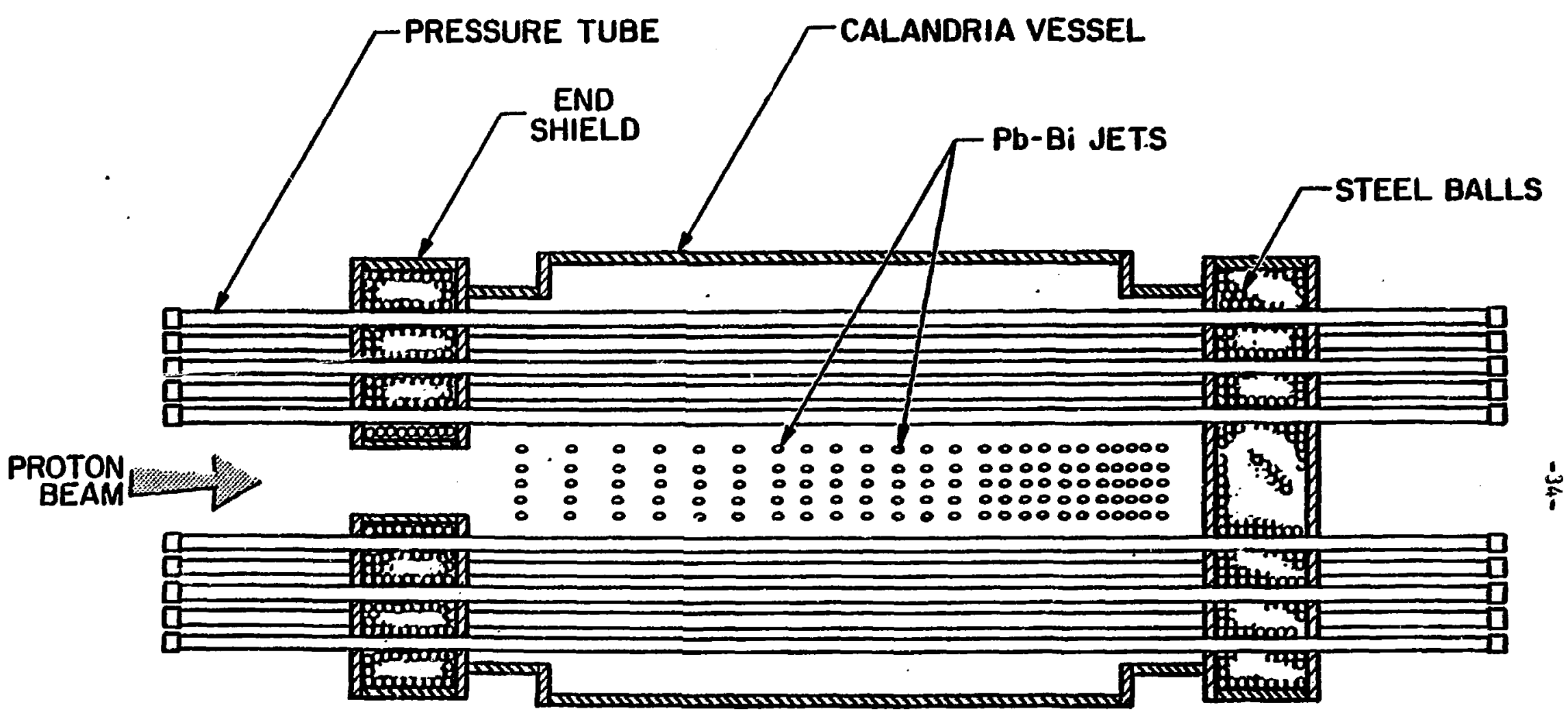

HWR TYPE TARGET ASSEMBLY, CROSS SECTION 
FIGURE 10

DIAGRAM OF CALCULATION PP.OCEDURE USED AT BNL

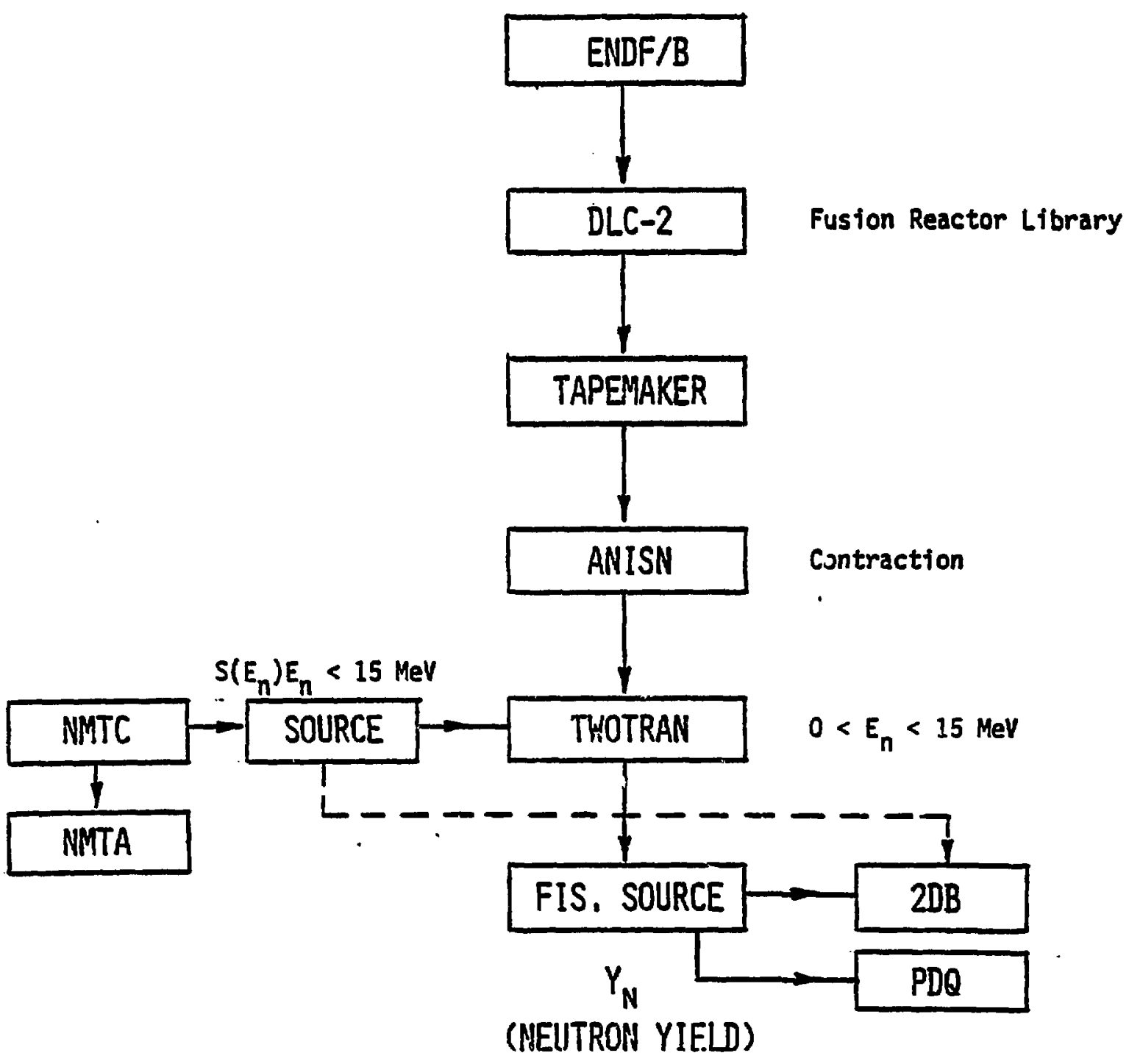


FIGURE 11

\section{MONTE CARLO CALCULATIONS}

FOR $P_{B}$ AND $\mathrm{UO}_{2}$

NEUTRONS PRODUCED BY REACTIONS OF GREATER THAN OR EQUAL TO 15 MEV EXCITATION ENERGY

NEUTRONS/I GEV PROTON.

\begin{tabular}{|c|c|c|}
\hline BATCH & $P_{B}$ & $\mathrm{UO}_{2}$ \\
\hline 1 & 37.84 & 35.24 \\
\hline 2 & 34.32 & 32.04 \\
\hline 3 & 36.16 & 34.08 \\
\hline 4 & 33.60 & 38.80 \\
\hline 5 & 37.96 & 36.12 \\
\hline 6 & 30.36 & 37.52 \\
\hline 7 & 30.44 & 34.84 \\
\hline 8 & 38.78 & 38.68 \\
\hline 9 & 34.00 & 29.80 \\
\hline 10 & 38.48 & 33.68 \\
\hline AVERAGE $Y$ & 35.192 & $35.080^{*}$ \\
\hline \multicolumn{3}{|c|}{$\begin{array}{l}\text { INFINITE MEDIUM, I GEV PROTON INJECTED INTO CENTER } \\
\text { LOWEST ENERGY I5 MEV. }\end{array}$} \\
\hline
\end{tabular}


FIGJJRE 12

MONTE CARLO CALCULATIONS FOR WATER/UO2 2 SYSTEM

NEUTRONS PRODUCED BY REACTIONS GREATER THAN

OR EQUAL TO 15 MEV EXCITATION ENERGY

NEUTRONS/1 GEV PROTON

$\left(\mathrm{V}_{\mathrm{H}_{2} \mathrm{O}} \mathrm{N} \mathrm{N}_{\mathrm{UO}_{2}}\right) ;\left(\mathrm{oH}_{2} \mathrm{O}\right)$

\begin{tabular}{cccccc}
\hline BATCH \# & $(2) ;(0.7)$ & $(1) ;(0.7)$ & $(.5) ;(0.7)$ & $(.5) ;(0.35)$ & $(.5) ;(0.175)$ \\
\hline 1 & 28.00 & 31.80 & 31.84 & 29.92 & 36.24 \\
2 & 21.84 & 27.68 & 23.60 & 33.52 & 35.96 \\
3 & 34.44 & 28.92 & 28.48 & 27.40 & 29.84 \\
4 & 29.04 & 30.40 & 21.52 & 27.64 & 28.76 \\
5 & 29.16 & 25.84 & 33.48 & 31.16 & 30.56 \\
6 & 21.24 & 29.64 & 26.84 & 38.72 & 26.64 \\
7 & 31.04 & 24.76 & 30.80 & 28.28 & 30.72 \\
8 & 24.64 & 27.76 & 28.16 & 36.24 & 30.00 \\
9 & 30.52 & 28.80 & 27.16 & 27.48 & 34.28 \\
10 & 26.40 & 36.16 & 32.32 & 27.24 & 26.32 \\
AVG. Y & $=27.632$ & 29.176 & 28.420 & 29.760 & 30.932 \\
\hline
\end{tabular}

\section{NATURAL URANIUM-WATER}

INFINITE MEDIUM

1 GEV PROTON INJECTEI INTO CENTER 


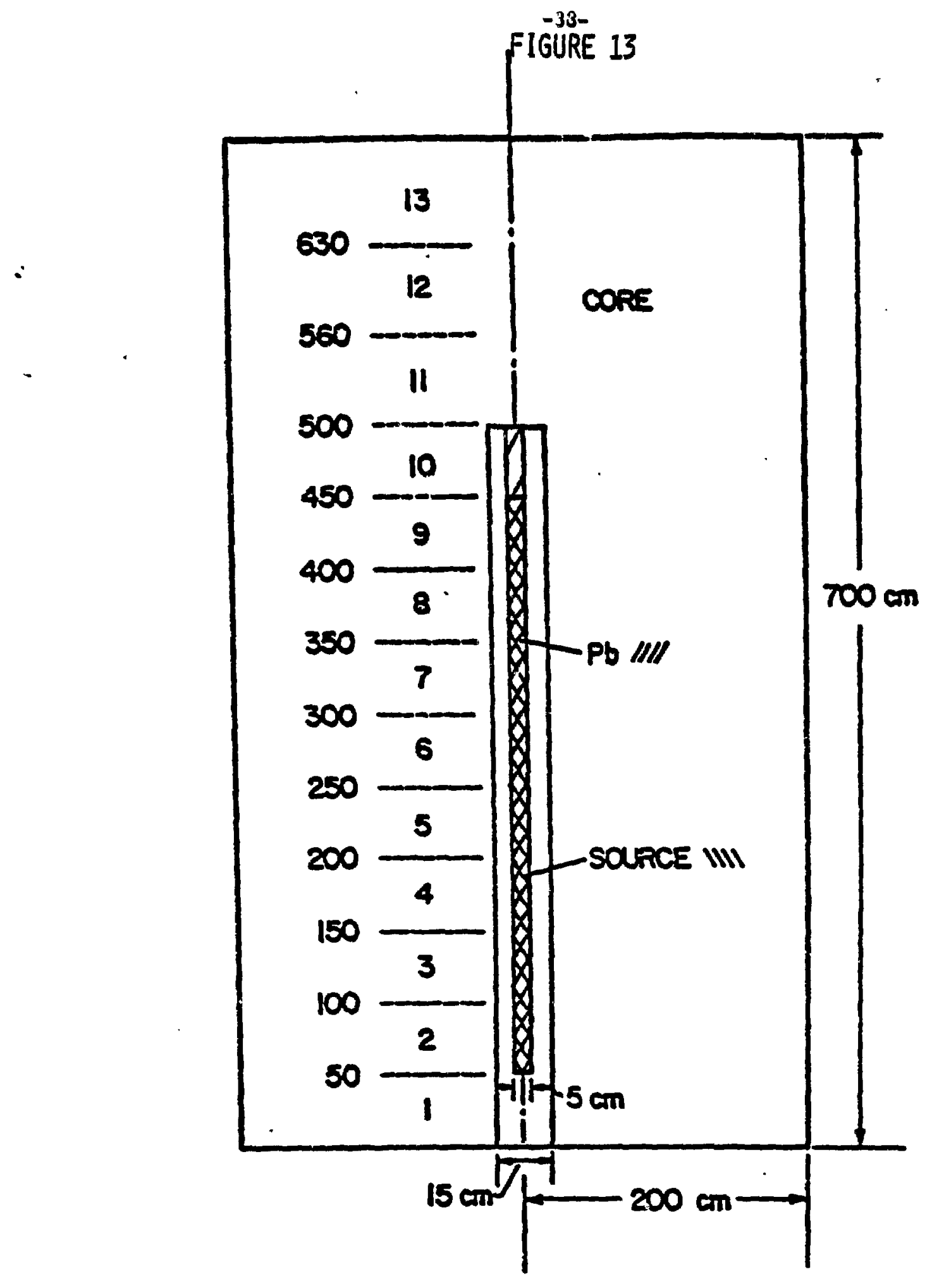

GEOMETRY OF BNL - CONCEPTULAL DESIGN 
FISSILE FUEL PRODUCTION CHARACTERISTICS FOR

$P_{B}-B 1 / F U E L$ ELEMENT TARGET ASSEMBLIES

PROTON ACCELERATOR 300 MA - 1 GEV

\begin{tabular}{|c|c|c|c|c|c|c|}
\hline $\begin{array}{l}\text { Design } \\
\text { MUMBer } \\
\end{array}$ & $\begin{array}{c}\text { INITIAL NEUTRON } \\
\text { YIELD } Y_{N} \\
\text { (INCLUDES FISSION } \\
\text { REACTION) } \\
\end{array}$ & $\begin{array}{r}\text { INITIAL } \\
\text { RATE } \\
\text { MA } \\
\text { (TT }\end{array}$ & $\begin{array}{l}\text { PrODUCTION } \\
\text { OF FUEL } \\
\text { TERIAL } \\
\text { ON/YR) } \\
\end{array}$ & $\begin{array}{l}\text { FERTILE } \\
\text { MATERIAL }\end{array}$ & Conlant & $\begin{array}{c}\text { Density of } \\
\text { COOLANT } \\
(\mathrm{G} / \mathrm{CC}) \\
\end{array}$ \\
\hline 1 & 35.9 & $\mathrm{Pu}$ & -0.93 & $\mathrm{UO}_{2}$ & $\mathrm{D}_{2} \mathrm{O}$ & 0.7 \\
\hline 2 & 31.1 & $u^{233}$ & -0.81 & $T_{H}$ & $D_{2}{ }^{0}$ & 0.7 \\
\hline 3 & 49.4 & Pu & -1.28 & $\mathrm{UO}_{2}$ & $\mathrm{H}_{2} \mathrm{O}$ & 0.7 \\
\hline 4 & 43.9 & $\mathrm{Pu}$ & -1.14 & $\mathrm{UO}_{2}$ & $\mathrm{H}_{2} \mathrm{O}$ & 0.35 \\
\hline 5 & 43.3 & Pu & -1.13 & $\mathrm{UO}_{2}$ & $\mathrm{H}_{2} \mathrm{O}$ & 0.175 \\
\hline 6 & 31.0 & $u^{233}$ & -0.81 & $T_{H}$ & $\mathrm{H}_{2} \mathrm{O}$ & 0.7 \\
\hline 7 & 32.4 & $u^{233}$ & -0.84 & $T_{H}$ & $\mathrm{H}_{2} \mathrm{O}$ & 0.35 \\
\hline 8 & 32.7 & $u^{233}$ & -0.85 & $T_{H}$ & $\mathrm{H}_{2} \mathrm{O}$ & 0.175 \\
\hline & & MODEI & /FUEL V & T10 & & \\
\hline
\end{tabular}


FIOURE 15

AVERAGE HEAT FIOUXX FOR PY/R FUEL

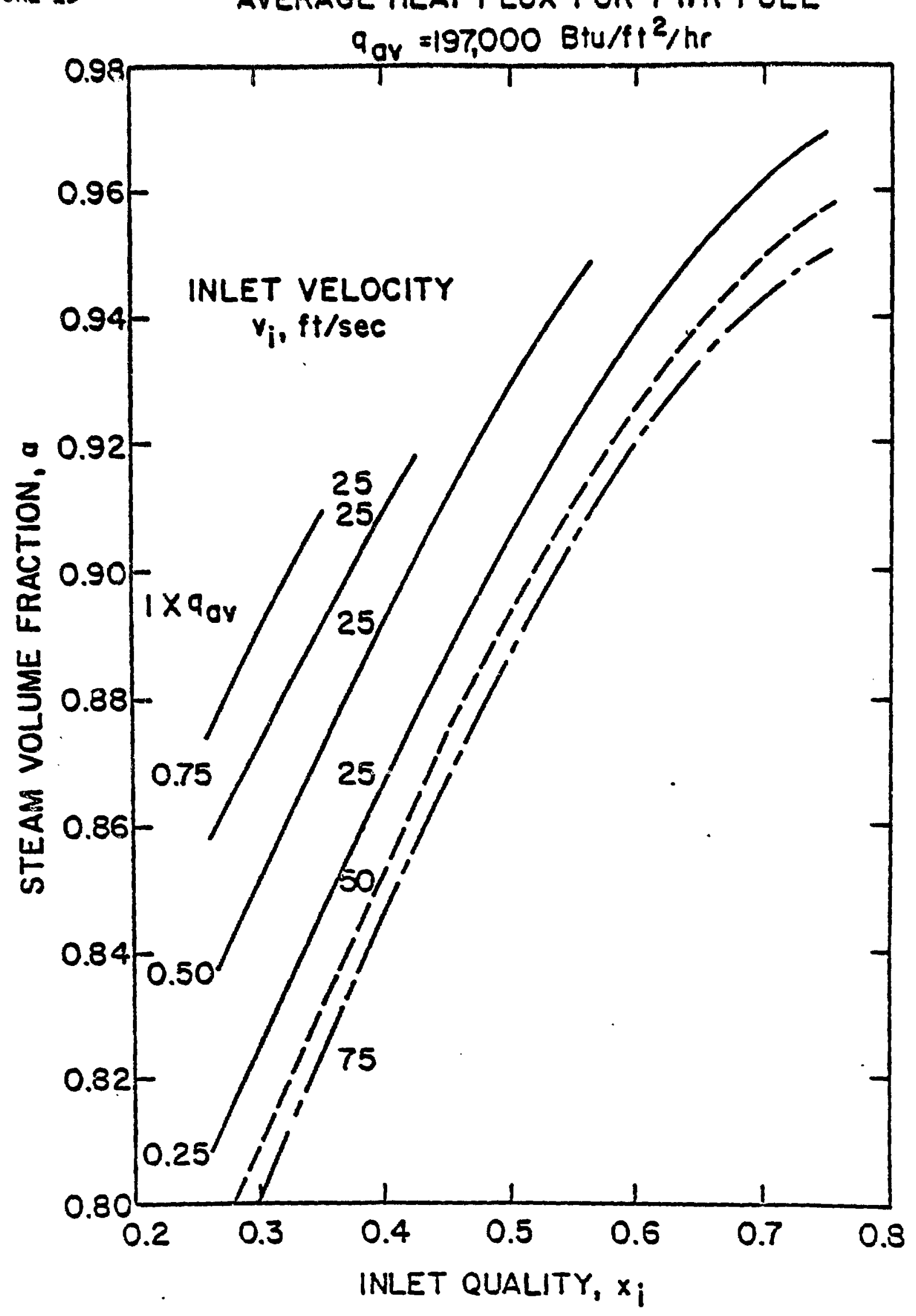


FIGURE 16

AVERAGE HEAT FLUX FOR PWR FUEL

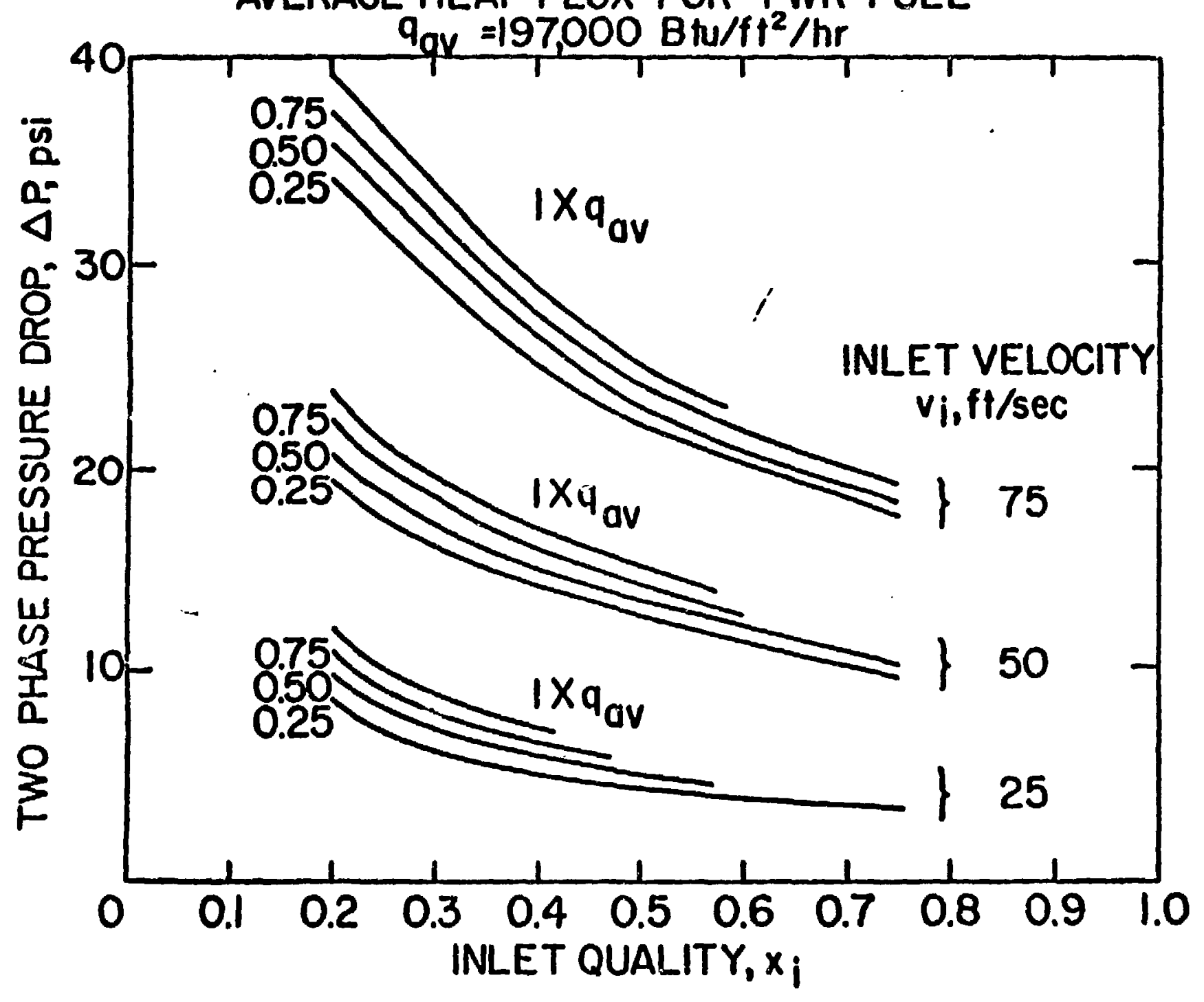




\section{FIGURE 17}

CONVENTIONAL NUCLEAR FIHLI. CYCLE - INR

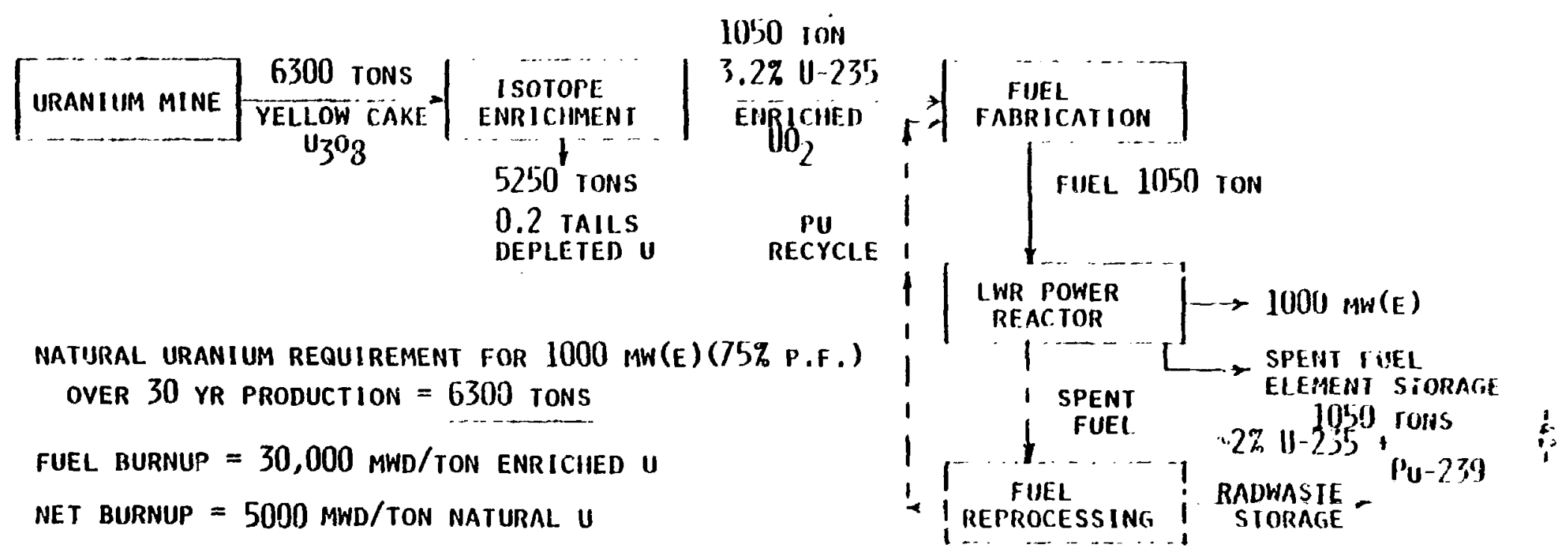


LAFR FUEL CYCLE - NO REPROCESSING

500 TONS

URANIUM MINE $\frac{1400 \text { TONS }}{\text { YELLOW CAKE }}\left[\begin{array}{c}\text { I SOTOPE } \\ \text { ENRICHMENT }\end{array}\right]$

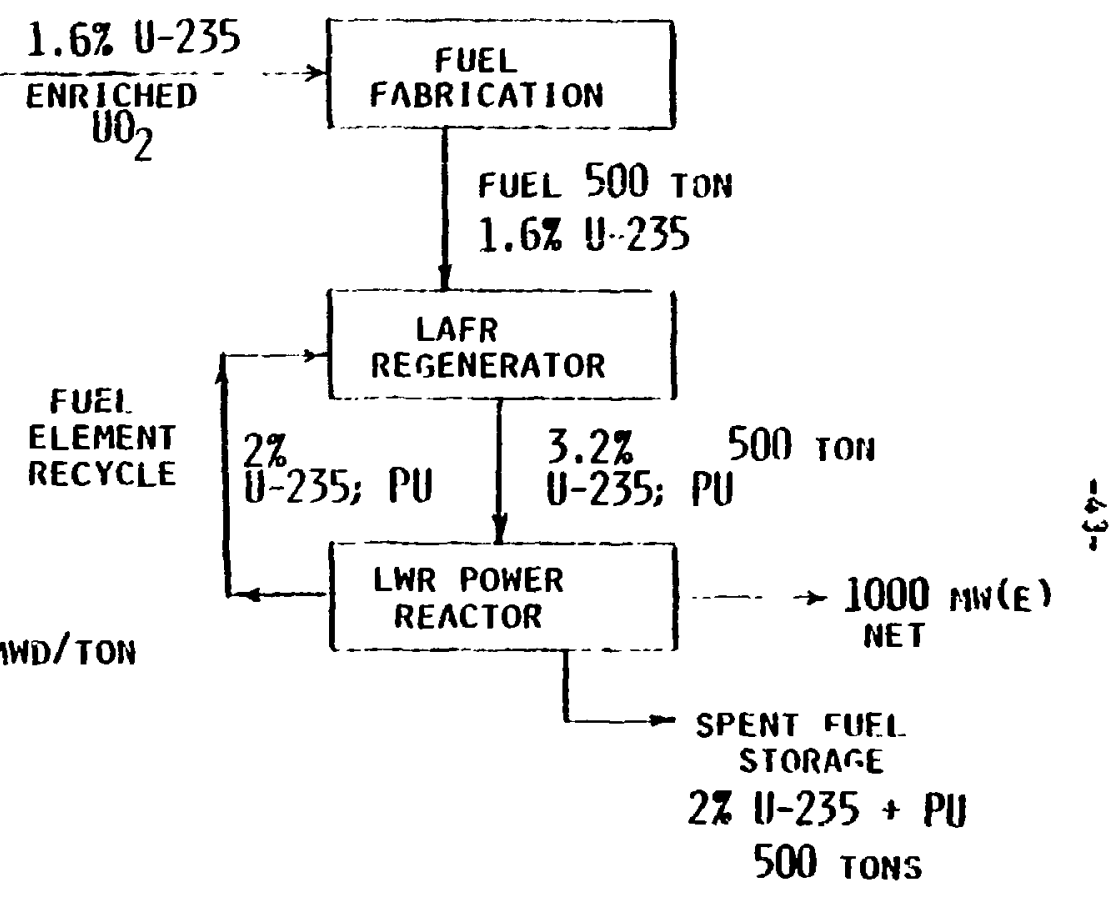

NATURAL URANIUM REQUIREMENT FOR $1000 \mathrm{MW}(\mathrm{E})$ (75\% P.F.)

LAFR-LWR OVER 30 YR PRODUCTION $=1400$ TONS

BURIUUP IN POHF.R REACTOR, 2 BURN CYCLES AT 30,000 MWD/TON

EXPOSURE IN LAFR $=6,000$ MWD/TON MAX. PER CYCLE

NET RESOURCE GAIN $=4.2 \times$

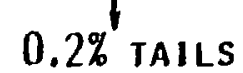


FIGURE 19

\section{FUELING CYCLE FOR LAFR-LHR SYSTEM}

\section{MW(E) LWR}

REACTOR CORE LOADING $=100 \mathrm{MT}$

ANNUAL RELOAD $=33$ MT

\begin{tabular}{c} 
END $\underset{\text { OF REACTOR }}{\text { YEAR }}$ \\
\hline 0 \\
1 \\
2 \\
3 \\
4 \\
5 \\
6 \\
7 \\
8 \\
9
\end{tabular}

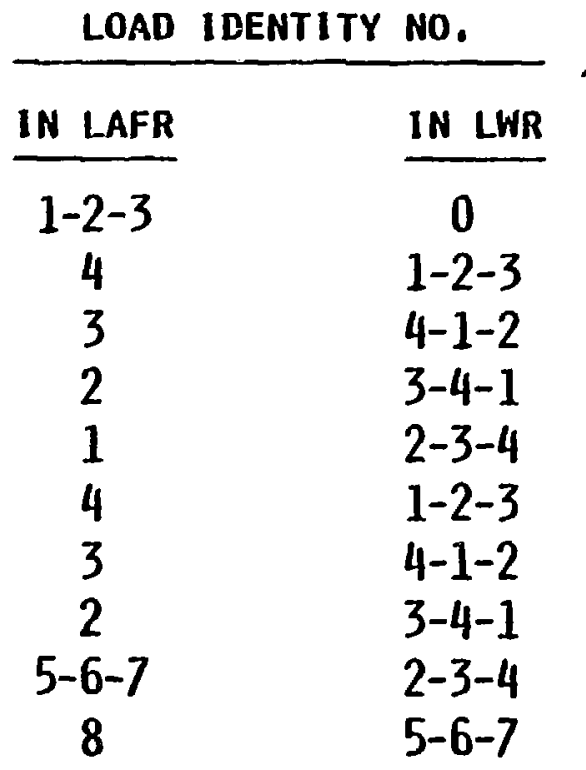

EACH LOAD IN LWR FOR 6 YEARS AT 10,000 MWD/MT $=60,000$ MWD/MT FIRST CYCLE IS 8 YEARS - (ON EQUIL. CYCLE 6 YEARS)

ONE LWR CORE LOADING NAT U REQUIREMENT $=2.8 \times 100=280$

+ INVENTORY IN LAFR

$=33 \times 2.8=92$

ENR. FACTOR $(0.7$ TO $1.6 \%)=2.8$

TOTAL $=372 \mathrm{MT}$

- total 30 yr nat u ReQuirement $=30 / 8 \times(372)$

RESOURCE GAIN

$=6300 / 1400$

$=1400 \mathrm{MT}$

$=4.5 \times$

IN 3 REGION CORE $3.2 \%-2.8 \%-2.4 \% \rightarrow 2.0 \%$ OUT

- ON EQUILIBRIUM BASIS $30 / 6 \times 280$

$=1400 \mathrm{MT}$ 


\section{FIGURE 20}

LIMEAR ACCELERATOR FUEL REGEMERATOR FOR LUR ECOMOHY

1 LAFR FEEDING 3 LMRS

MATURAL URANIUM RESOURCE GAIM OVER PRESENT LWR ECOHOMY

30 YR Lifetime - 1000 MW(E) PHR MEeds - 6300 Mt MAT $\mathrm{vO}_{2}$

\begin{tabular}{cccc}
$\begin{array}{c}\text { NO. OF BURN CYCLES } \\
\text { AT 30,000 MHD/MT EA. }\end{array}$ & $\begin{array}{c}\text { TOTAL LWR } \\
\text { BURNUP } \\
\text { MHD/MT }\end{array}$ & $\begin{array}{c}\text { I LAFR/3 LHR } \\
\text { HAT U0, } \\
\text { MTEDS }\end{array}$ & $\begin{array}{c}\text { MATURAL U } \\
\text { RESOLPCE GAIN }\end{array}$ \\
\hline 1 & 30,000 & 2,800 & 2.3 \\
\hline 2 & 60,000 & 1,400 & 4.5 \\
\hline 3 & 90,000 & 933 & 6.8 \\
4 & 120,000 & 700 & 9.0 \\
5 & 150,000 & 560 & 11.3
\end{tabular}

(") FOR $1.6 \%$ U-235 ENRICHMENT FEED TO LAFR. 
FIGURE 21

LINEAR ACCELERATOR FUEL REGENERATOR WITII LIGHT HATER REACTORS (1 LAFR/3 LHR)

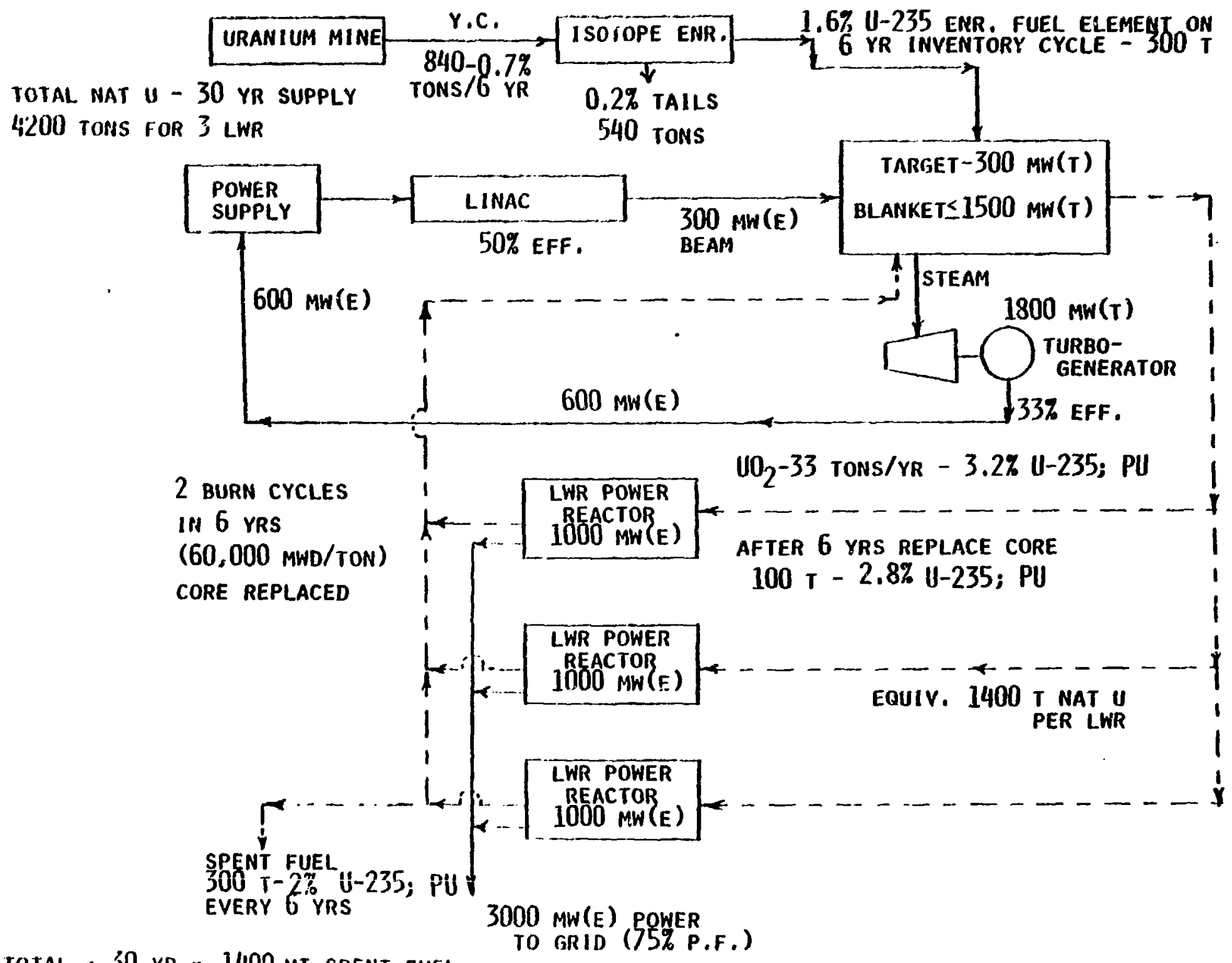




\section{FIGURE 22}

COMPARATIVE ECONOMICS OF LINEAR ACCELERATOR FUEL REGENERATOR WITH LIGHT WATER REACTORS

BASE CAPITAL COST FOR LAFR + 3-1000 MW(E) LWRS (1977 DOLLARS)

LINAC 600 MW(E) $\times 1000 \times \frac{\$ 600}{\text { KW(E) }}$

$=\$ 360 \times 10^{6}$

TARGET REACTOR $=600 \mathrm{MW(E)} \times 1000 \times \frac{\$ 600}{\text { KW(E) }}$

$=\$ 360 \times 10^{6}$

LAFR $=720 \times 10^{6}$

COST of 3-1000 HW(E) LWRS $=3 \times 1000 \times 1000 \times \frac{\$ 600}{\text { KW(E) }}$

TOTAL DIRECT CAPITAL COST

UNIT COST OFLAFR PLUS $3-1000$ MH(E)
WITH NET POWER $=3000$ MW(E)

$=1,800 \times 10^{6}$

$=2,520 \times 10^{6}$

UNIT COST OF LWR

$=\$ 600 / \mathrm{KW}(\mathrm{E})$

UNIT CAPITAL COST RATIO LAFR-LWR/LWR

$=1.4$ 


\section{FIGURE 23}

COAPARATIVE ECONOMICS OF LINEAR ACCELERATOR FUEL REGESIERATOR (LAFR) WITH LIGHT WATER REACTORS (LHR)

\section{CAPITAL COST}

BASE CAPITAL COST $\$ / \mathrm{KW}$

COMPLETION COST \$/KW (ESCALATED FOR 1986 OPERATION)

RESOURCE

FUEL REQUIREMENT OVER 30 YEARS, TONS NAT, U

POHer gemeration COSt (AVERAge 1ST-10 yrs)

CAPITAL CHARGES (15\% AND 70\% L.F.)

FUEL (5\% ESCALATION/YRL

OP, \& MAINT.

TOTAL

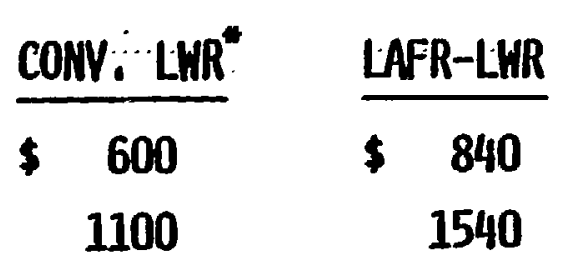

\begin{tabular}{|c|c|}
\hline 6300 & 1400 \\
\hline \multicolumn{2}{|c|}{ MILLS/KWH(E) } \\
\hline 26.9 & 37.7 \\
\hline 13.3 & 4.4 \\
\hline 3.3 & 4.0 \\
\hline $43.5^{*}$ & 46.1 \\
\hline
\end{tabular}

(") ANS INDUSTRY REPORT (1976-7) - BECHTEL ESTIMATE. CONCLUSION - LAFR/3 LWR REASONABLY COMPETITIVE WITH LHR. 
FIGURE 24

$\frac{\text { FUEL CYCLE COST - MILLS/KNH(E) }}{\text { (ESCALATED TO 1986) }}$

\begin{tabular}{|c|c|c|c|c|}
\hline & $\begin{array}{l}\text { UNIT COST } \\
1977 \\
\text { DOLLARS }\end{array}$ & LWR & $\begin{array}{l}\text { REDUCTION } \\
\text { FACTOR }\end{array}$ & $\begin{array}{l}\text { 2-CYCLE } \\
\text { LAFR-LKR }\end{array}$ \\
\hline YELLOW CAKE & $\$ 50 / L B \quad U_{3} O_{8}$ & 3.94 & 4.5 & 0.88 \\
\hline CONVERSION & $\$ 11 / K G$ & 0.29 & 4.5 & 0.06 \\
\hline ENRICHMENT & $\$ 100 /$ swu & 2.90 & 9.0 & 0.32 \\
\hline FABRICATION & $\$ 200 /$ KG & 2.05 & 2.0 & 1.03 \\
\hline $\begin{array}{l}\text { STORAGE AND } \\
\text { CARRYING CHARGE }\end{array}$ & $\$ 400 / \mathrm{KG} \mathrm{HM}$ & 3.87 & 2.0 & 1.94 \\
\hline \multirow[t]{2}{*}{ TRANSPORTAFION } & $\$ 30 /$ KG HM & 0.31 & 2.0 & 0.15 \\
\hline & & 13.36 & & $\overline{4.38}$ \\
\hline
\end{tabular}

(") INDUSTRY REPORT (1976-7) - BECHTEL ESTIMATE. 


\section{FISSILE FUEL PRODUCTION ECOMOMICS}

\section{CAPACITY}

BEAM POWER - MW(E)

POWER TO ACCEL. - MW(E)

RECirCULATING POWER - MW(E) (MAX)

OUTSIDE POWER REQUIRED - MW(E)

FUEL PRODUCTION RATE - KG/YR

CAPITAL COST

LINAC - 300 MW(E) BEAM

TARGET 600 MW(E)

DIRECT CAPITAL

COMPLETED COST (ESCALATED 1986)

PRODUCTION COST OF U-233 - FISSILE MATERIAL

DEPRECIATION (15\% PER ANNUM).

FUEL CYCLE

O\&M
LAFR OR LAFP

300

600

600

0

1200 Pu-239 OR

$1180 \mathrm{U}-233$

$$
\begin{array}{r}
\$ 360 \times 10^{6} \\
360 \times 10^{6} \\
\hline 720 \times 10^{6} \\
1,320 \times 10^{6}
\end{array}
$$

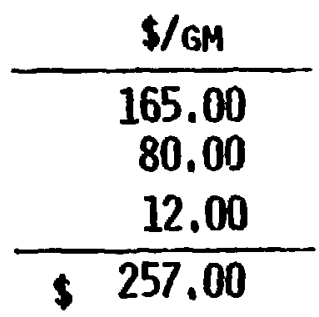

PRODUCTION COST - \$/GM FISSILE MAT, PRODUCED \& CONSIMED

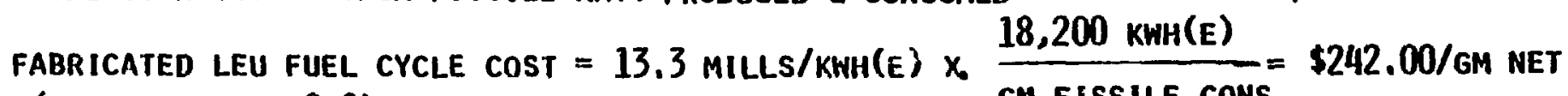

(CONV. RATIO $=0.6$ )

GM FISSILE CONS. FISSILE MAT. CONSUMED

(\$96.00/GM INITIAL U-235

CONCLUSION - LAFR FUEL COST WITHIN $10 \%$ OF U-235 COST. CONTAINED IN FUEL ELEMENT) 


\section{CONCLUSIONS FROM ECONOMIC ESTIMATES}

- Lafr in Range of LHR cost - tradeoff fuel cost for capital cost

- extend fuel supply 4.5 times based on

A) BURNUP OF 60,000 MWD/TON

B) NO REPROCESSING

c) THROMAWAY FUEL CYCLE

- reduces enrichment plant requirements significantly (est, 9,0 X less SWl's)

- USES LHR POWER TEChNOLOgY

- LAFR IS AN INDEPENDENT SOURCE OF SUPPLY OF IN-SITU ENRICHEd FUEL

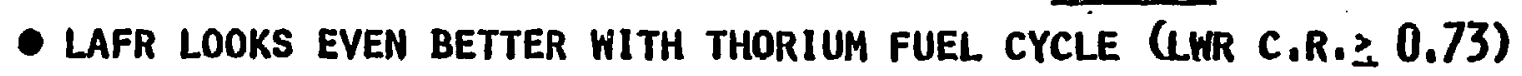

- COST DECREASES LESS fOR gREATER THAN 2 BURN CYCLES

- INCREASES RESOURCE UTILIZATION SIGNIFICANTLY 


\section{FIGURE 27}

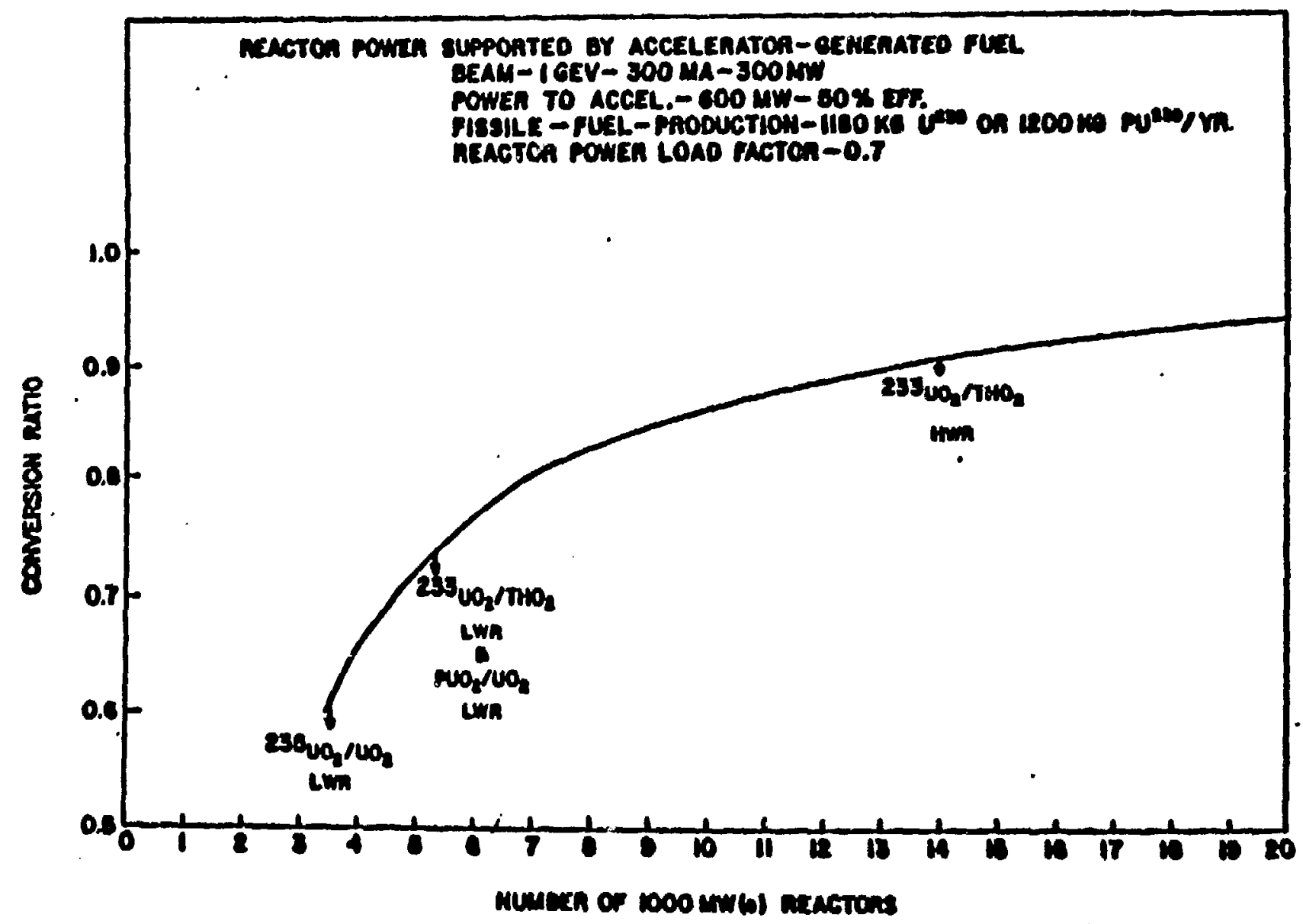




\section{FIGUPE 28}

REACTOR POWER SUPPORTED BY ACCELERATOR GENERATED FUEL

POWER COST FOR I AMD TH FUEL CYCLES

ACCEL. BEAM POWER $=300 \mathrm{MW}-$ POWER $793^{\text {ACCEL }}=600 \mathrm{~mW}(\mathrm{SE})$

FISSILE FUEL PRODUCTION - $1180 \mathrm{KG} \mathrm{U} \mathrm{U}^{233}$ OR $1200 \mathrm{KG} \mathrm{PU} 239 / \mathrm{YR}$

REACTOR POWER LOAD FACTOR $=0.7$

\section{REACTOR TYPE}

FUEL FROM. LAFP

CONYERSION RATIO

TOTAL REACTOR POWER SUPPORTED, MW(E)

POWER COST FOR 1000 MH(E) REACTOR

FUEL CYCLE

$0 \& M$

HEAVY WATER

DEPRECIATION (15\%/YR)

TOTAL PRODUCTION COST

RESOURCE ENTENDED WITH LAFR - NO REPROCESSING (X PRESENT LWR THROWAWAY)

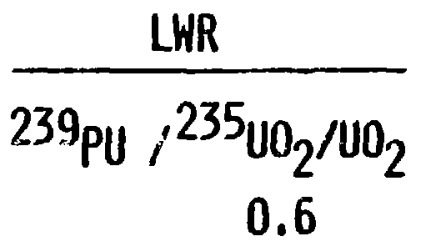

3400

$\frac{\text { IHR }}{{ }^{233 \mathrm{UO}_{2} / \mathrm{THO}_{2}}}$

0.73

5000

MILLS/KIHH(E)

\begin{tabular}{ccc}
14.1 & 9.5 & 3.5 \\
3.3 & 3.3 & 3.3 \\
-- & -- & 2.2 \\
26.9 & 26.9 & 26.9 \\
\hline 44.3 & & \\
$4.5 \times$ & 39.7 & 35.9 \\
& $6.7 \times$ & $18.0 \times$
\end{tabular}


FIGURE 29

\section{LINEAR ACCELERATOR FIJEL PRODUCER AND REGENERATOR}

TH/U-233 TOPPING OF ENRICHED U/U-235

DENATURED FUEL CYCLE

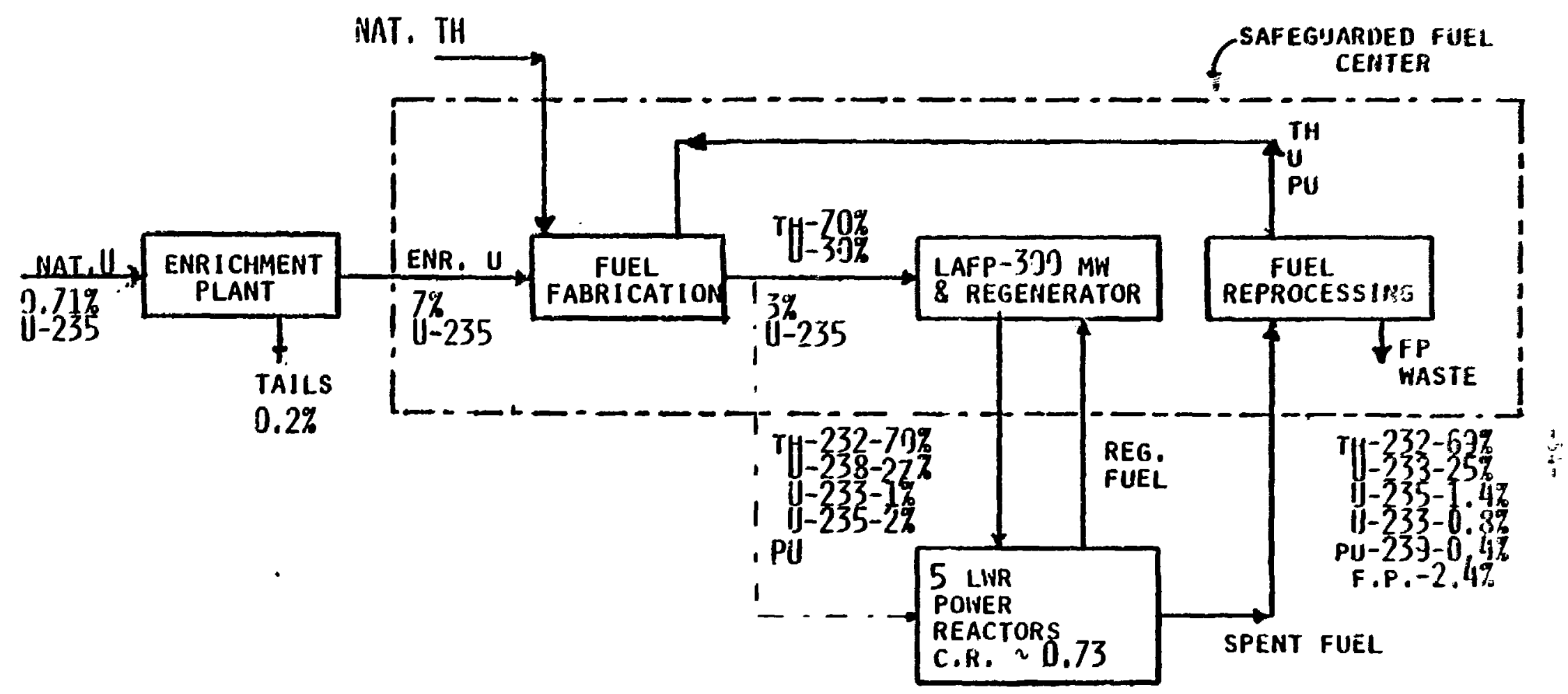


FIGURE 30

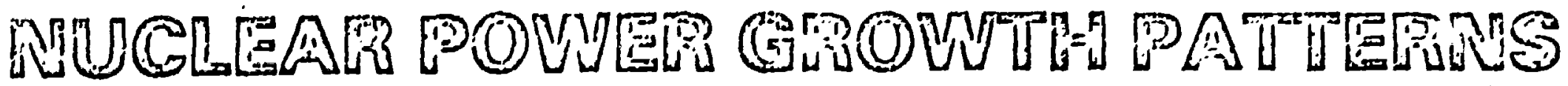
EFFECT OF DENATUAED SYSTENIS SMALL U $\mathrm{U}_{3} \mathrm{O}_{8}$ SUPPLY.

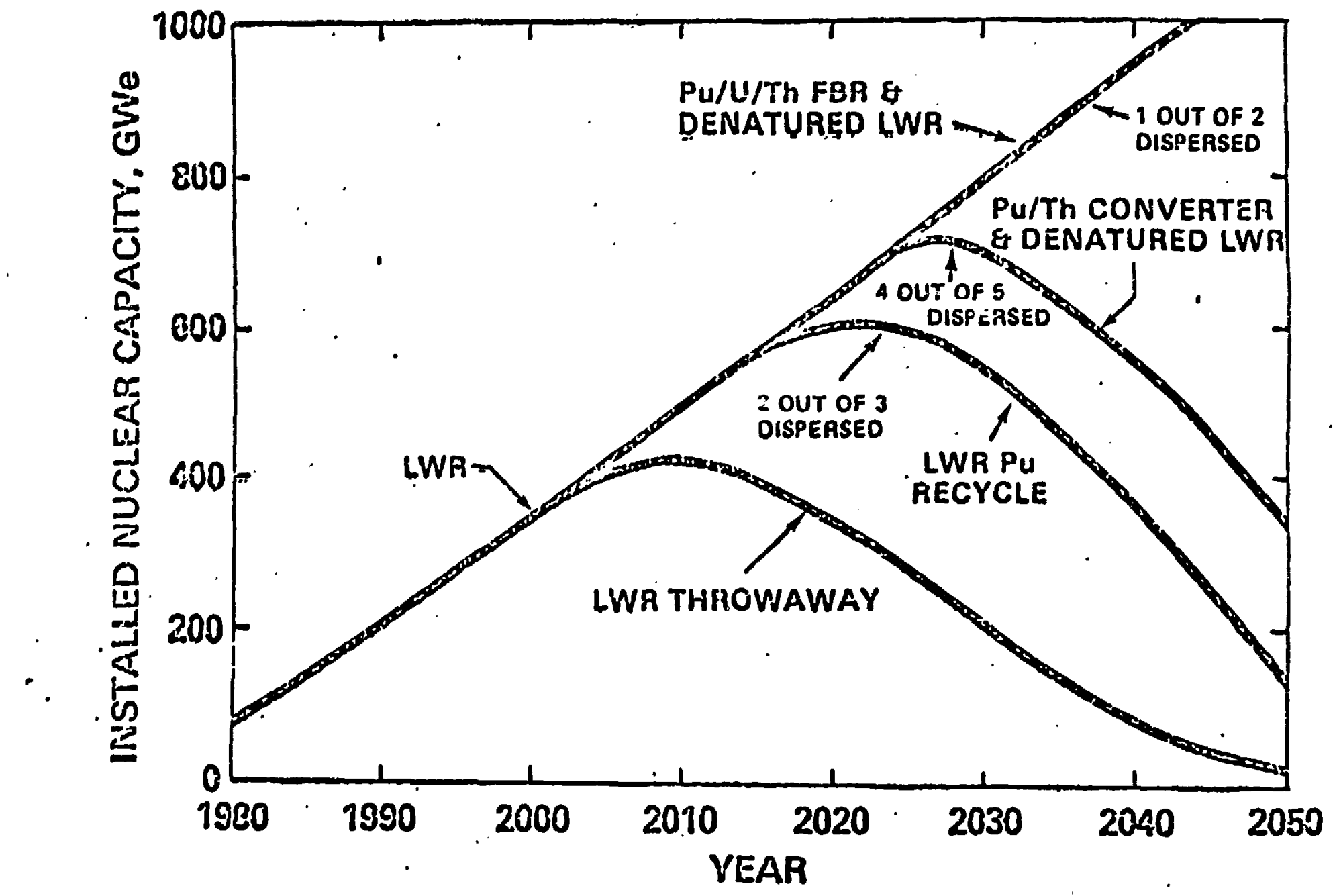


FIGURE 31

NUCLEAR POWER GROWTH PATTERNS

EFFECT OF LAFP SYSTEMS (SMALL $U_{3} 0_{8}$ SUPPLY)

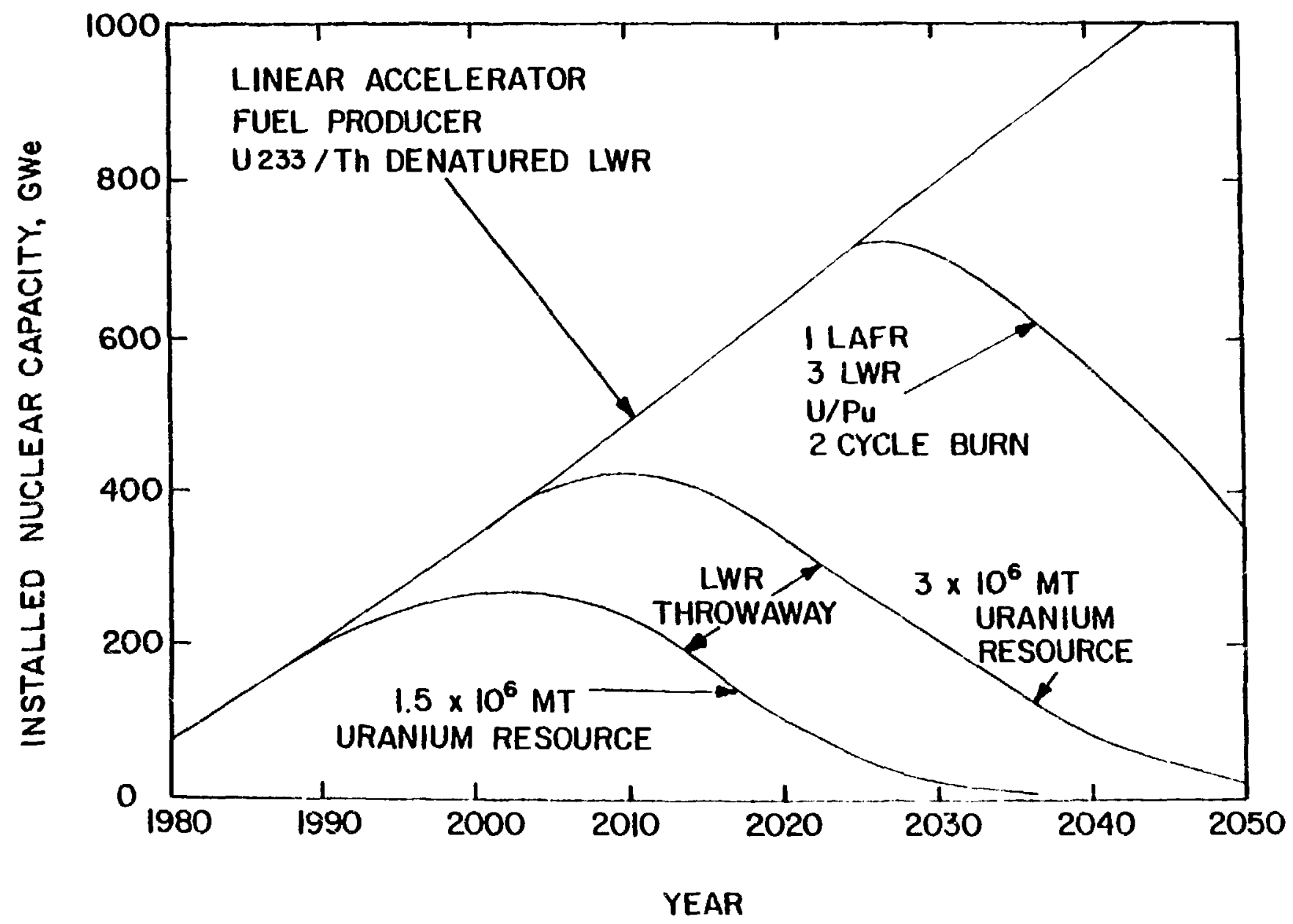


FIGURE 32

\begin{tabular}{|c|c|c|c|c|c|}
\hline & & & & & \\
\hline & \multirow[b]{2}{*}{$\begin{array}{l}\text { U-235 ENRICHMENT } \\
\text { PLANT } \\
\end{array}$} & \multicolumn{2}{|c|}{ INTERNAL NEUTRON SOURCE } & \multicolumn{2}{|c|}{ EXTERNAL NEUTRON SOURCE } \\
\hline & & LWR & LMFBR & HYBRID & $\begin{array}{l}\text { ACCELERATOR } \\
\text { LAFR/LAFP } \\
\end{array}$ \\
\hline CAPITAL COST (1986) & $\begin{array}{c}\$ 1 \times 10^{9} \\
1.5 \times 10^{6} \text { swu }\end{array}$ & $\$ 1 \times 10^{9}$ & $\$ 1.4 \times 10^{9}$ & $\$ 3.7 \times 10^{9}$ & $\$ 1.3 \times 10^{9}$ \\
\hline PU PRODUCTION MT/YR & $101035)$ & 0.3 & $0.1-0.3$ & 1.5 & 1.0 \\
\hline U-233 PRODUCTION MT/YR & -- & 0.4 & $0.1-0.3$ & 1.5 & 1.0 \\
\hline POWER DELIVERED MH(E) & $\begin{array}{l}-65 \mathrm{MW} \\
\text { CONS }\end{array}$ & 1000 & 1000 & .500 & 0 \\
\hline FUEL REQUIREMENT & $-\infty$ & $\begin{array}{l}\text { SMALL FISSILE } \\
\text { LEU OR PU SOURCE }\end{array}$ & $\begin{array}{l}\text { LARGE -FISSILE } \\
\text { SOURCE }\end{array}$ & $\begin{array}{l}\text { FERTILE } \\
\text { FUEL ONLY }\end{array}$ & $\begin{array}{l}\text { FERTILE } \\
\text { FUEL ONLY }\end{array}$ \\
\hline $\begin{array}{l}\text { LIFETIME FERTILE FUEL } \\
\text { MEQUIREMENT, MT } \\
\text { MO REPROCESSING)-30 YR }\end{array}$ & 60,000 & $\begin{array}{l}6000 \\
\text { WITH ENRI ICHMENT }\end{array}$ & $\begin{array}{l}\text { CANMOT } \\
\text { FUNCTION }\end{array}$ & 2100 & $\begin{array}{l}1400 \\
\text { CON TH-y } \\
\text { CYCLE } \leq 500\end{array}$ \\
\hline $\begin{array}{l}\text { LIFETIME FERTILE FUEL } \\
\text { REQUIREMENT, MT } \\
\text { WITH REPROCESSING)-30 YR }\end{array}$ & 40,000 & 4000 & 30 & $30^{\circ}$ & $30 \stackrel{i}{i}$ \\
\hline SYSTEM SUPPORT & $\begin{array}{l}1 \text { ENRICH. } \\
\text { PLANT. SUPPORTS } \\
10-15 / \text { LWR }\end{array}$ & $\begin{array}{l}1 \text { LWR } \\
\text { CANNOT SUPPORT } \\
\text { ANY LWR }\end{array}$ & $\begin{array}{l}1 \text { PU BREEDER } \\
\text { SUPPORTS } 1 \\
\text { PU/LWR } \\
\text { NO DENATURED LWR }\end{array}$ & $\begin{array}{l}1 \text { PU HYBR } \\
\text { SUPPORTS } 5 \\
\text { OR } 20 \text { ON TH- }\end{array}$ & $\begin{array}{l}1 \text { PU LAFP } \\
\text { LWR SUPPORTS } \\
\begin{array}{l}3 \\
12\end{array} \text { ON TH TH- }\end{array}$ \\
\hline $\begin{array}{l}\text { FLEXIBILLITY FOR } \\
\text { LWR ECONOMY }\end{array}$ & $\begin{array}{l}\text { SEVERELY } \\
\text { LIMITED BY } \\
\text { NAT U RESOURCE }\end{array}$ & $\begin{array}{l}\text { SEVERELY } \\
\text { LPMITED BY } \\
\text { NAT U RESOURCE }\end{array}$ & $\begin{array}{l}\text { LIMITED BY } \\
\text { POWER CONSUMP- } \\
\text { TION GROWTH } \\
\text { RATE }\end{array}$ & No. & $\begin{array}{l}\text { No } \\
\text { LIMITA- } \\
\text { TIONS }\end{array}$ \\
\hline
\end{tabular}


FIGURE 33

- COMPARISON OF LONG-TERM FISSILE FUEL PRODUCTION SYSTEM

(BASIS; 500 GW(E) MET POWER)

FBR + LHR $\quad \frac{\text { LAFP + LHR }}{U / P U T H / U} \cdots \frac{\text { HYBRID + LHR }}{U / P U \cdot T H / U}$

TOTAL SYSTEM CAPITAL (1986 ESC, \$)

INVESTMENT (\$BILLIONS)

600

$725 \quad 630$

$780 \therefore 670$

NTI - NEW TEÇHNOLOGY

INVESTMENT (\$BILLIONS)

350

NO, OF LWR'S

SUPPLY RATIO

250
$. \mathrm{LWR} / \mathrm{FBR}$
$1 / 1$

225130

330200

NO. OF NTI PLANTS

250

LWR UNIT CAPITAL COST, \$KW(E)

1000

$500 \quad 500$

LWR/LAFR

$3 / 1 \quad 5 / 1$

$450 \quad 470$

LWR/HYBRID

$5 / 1 \quad 8 / 1$

NTI CAP TIAL COST PER PRODUCTION PLANT (\$BILLION)

R\&D COST $\left(10^{9}\right)$

$\frac{170 \cdots 100}{1000}$

$90 \cdot \cdots \cdot 55$

1000

COMMERCIAL INTRODUCTION DATE

1.4

3 CONCLUSION - TOTAL SYSTEM INVESTMENT 5-20\% MORE FOR LAF COMPARED

- AND FOR LONG TERM, THE UTILITY USES CONVENTIONAL LWR TECHNOLOGY, 
FIGURE 34

UNIQUE FEATURES OF

LINEAR ACCELERATOR FUEL PRODUCER AND REGENERATOR.

A LONG-TERM INDEPENDENT FUEL SUPPLIER FOR THE LMR POWER ECONOMY

- PROVIDES fLEXIBILITY IN LWR NUCLEAR fUeL CYCLE

- INSURES LONG-TERM USE OF LWR THERMAL REACTOR ECONOMY AT a COMPETITIVE COST

- OPENS UP LONG-TERM USE OF EXISTING NUCLEAR FUEL RESOURCE

- OPENS UP TH/U-233 FUEL CYCLE

- MAKES EFTICIENT USE OF EXISTING ENRICHMENT PLANTS

- DEPENDS ONLY ON EXTENSION OF EXISTING TECHNOLOGY - ACCELERATOR AND TARGET

- R\&D COST OF DEMONSTRATION AND IMPLEMENTATION IS CONSIDERABLY LESS THAN FOR HYBRID

- produces a highly proliferation resistant fuel cycle - th/u-233 denatured fuel

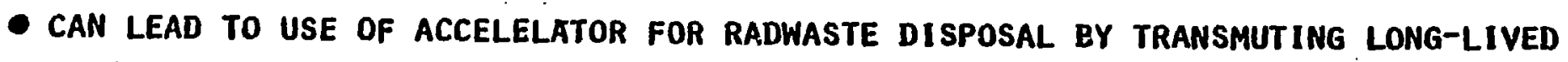
FISSION PRODUCTS AND TRANSURANICS TO SHORT-LIVED AND STABLE PRODUCTS 


\section{FIGURE 35}

RLD RERUIRED AND SCHEDULE FOR IMPLEMENTATION

\section{(1978 dollars)}

- target physics eXPeriment

$\begin{array}{rcc}\frac{M \$}{50} & & \frac{\text { YEAR }}{1980-1983} \\ 500 & & 1980-1990 \\ & & 1990 \\ 1,000 & & 2000 \\ 2,000 & \end{array}$
- ACCELERATOR AND TARGET COMPOH
DEVEL.
- DEMO PILOT PLANT AMD R\&D
- PROTOTYPE COMMERCIAL PLANT
AND RED DEVELLETOR AND TARGET COMPO
DEMO PILOT PLANT AMD RED
ROTOTYPE COMMERCIAL PLANT
AND RED 